\title{
Proteomics-based identification of differentially abundant proteins reveals adaptation mechanisms of Xanthomonas citri subsp. citri during Citrus sinensis infection
}

Leandro M. Moreira ${ }^{1,2^{*}}$, Márcia R. Soares ${ }^{3+}$, Agda P. Facincani ${ }^{4 *}$, Cristiano B. Ferreira ${ }^{4}$, Rafael M. Ferreira ${ }^{4}$, Maria I. T. Ferro ${ }^{4}$, Fábio C. Gozzo ${ }^{5}$, Érica B. Felestrino ${ }^{2}$, Renata A. B. Assis², Camila Carrião M. Garcia,2, João C. Setubal ${ }^{6,8}$, Jesus A. Ferro ${ }^{4}$ and Julio C.F. de Oliveira ${ }^{7}$

\begin{abstract}
Background: Xanthomonas citri subsp. citri (Xac) is the causal agent of citrus canker. A proteomic analysis under in planta infectious and non-infectious conditions was conducted in order to increase our knowledge about the adaptive process of Xac during infection.

Results: For that, a 2D-based proteomic analysis of Xac at 1, 3 and 5 days after inoculation, in comparison to Xac growth in NB media was carried out and followed by MALDI-TOF-TOF identification of 124 unique differentially abundant proteins. Among them, 79 correspond to up-regulated proteins in at least one of the three stages of infection. Our results indicate an important role of proteins related to biofilm synthesis, lipopolysaccharides biosynthesis, and iron uptake and metabolism as possible modulators of plant innate immunity, and revealed an intricate network of proteins involved in reactive oxygen species adaptation during Plants` Oxidative Burst response. We also identified proteins previously unknown to be involved in Xac-Citrus interaction, including the hypothetical protein XAC3981. A mutant strain for this gene has proved to be non-pathogenic in respect to classical symptoms of citrus canker induced in compatible plants.
\end{abstract}

Conclusions: This is the first time that a protein repertoire is shown to be active and working in an integrated manner during the infection process in a compatible host, pointing to an elaborate mechanism for adaptation of Xac once inside the plant.

Keywords: Xanthomonas, adaptation mechanisms, Biofilm, Iron uptake and metabolism, Plants'Oxidative burst, LPS modulation

\footnotetext{
* Correspondence: Immorei@gmail.com; agdapf1@yahoo.com.br

${ }^{\dagger}$ Equal contributors

'Departamento de Ciências Biológicas (DECBI), Instituto de Ciências Exatas e Biológicas (ICEB), Universidade Federal de Ouro Preto (UFOP), Ouro Preto, MG, Brazil

${ }^{4}$ Faculdade de Ciências Agrárias e Veterinárias de Jaboticabal, UNESP -

Universidade Estadual Paulista, Departamento de Tecnologia, Jaboticabal, SP, Brazil

Full list of author information is available at the end of the article
} 


\section{Background}

Xanthomonas citri subsp. citri (Xac) strain 306 pathotype $\mathrm{A}$ is the most aggressive causal agent of citrus canker, a disease that affects most citrus cultivars worldwide, causing considerable loss of fruits and their derivatives $[1,2]$. After Xac invades plant tissue, localized induced canker symptoms correspond to watersoaking (3 Days After Induction - 3DAI), hyperplasia (5DAI), and necrosis (about 14DAI) [3]. The infection process culminates into rupture of the plant tissue and dispersion of pathogens to other plants [4] (Additional file 1: Figure 1a and b).

Although described primarily as a plant pathogenic organism, before invading the plant tissues, $\mathrm{Xac}$, as well as other bacteria from the same genus, can develop as an epiphyte or saprophytic organism, which is capable of surviving outside the plant $[5,6]$. Under the impact of several abiotic factors, which already demonstrates its adaptive capacity to adverse conditions [7], Xac invades tissue of compatible plant hosts becoming a phytobacterium. Likewise, so that it can survive within the plant tissues, $X a c$ is adapted to stressful conditions imposed by the plant in the early periods of infection [8] and expresses genes related to pathogenicity and virulence [9].

The response to the invading organism may vary among plants depending on which plant-microorganism recognition and immunity pathway is triggered: the Effector-Triggered Immunity (ETI) or the PathogenAssociated Molecular Pattern-Triggered Immunity (PAMP-PTI) [10] (Additional file 1: Figure 1c). The highly conserved N-terminal domain of flagellin (flg22), for example, is characterized as a plant bacterial PAMP $[11,12]$. Lipopolysaccharides (LPS) and structural or secreted proteins also act as PAMPs [13]. The EffectorTriggered Immunity (ETI) pathway may occur in plants carrying the plant's resistance protein (R), which recognizes the pathogen's avirulence protein (Avr) [14]. The PAMP-PTI pathway triggers the expression of genes related to defense [15], which may occur by a MitogenActivated Protein Kinase (MAPK) cascade or by production of Reactive Oxygen Species (ROS) [16], culminating in regulation of the activity of genes involved in plant defense [17]. However, this process of molecular plantpathogen recognition and interaction is highly dynamic that some proteins secreted by the pathogen inhibit the cascade effect induced by PAMPs, modulating host response process against plant pathogen attack [18].

When the pathogen presence is detected the production of ROS is the earliest plant cell response, and the oxidative stress generated under this condition is a fundamental process called Plants` Oxidative Burst (POB) [19]. During the POB response, species such as superoxide anion radical $\left(\mathrm{O}_{2}^{\bullet-}\right)$, hydrogen peroxide $\left(\mathrm{H}_{2} \mathrm{O}_{2}\right)$, hydroxyl radical $\left(\mathrm{OH}^{\bullet}\right)$, and organic peroxides $(\mathrm{R}-\mathrm{OOH})$ are massively produced [16]. These compounds are very reactive, causing modifications in biomolecules such as DNA, RNA, proteins, lipids and their precursors, which cause defective cell function, including mutations and bacterial replication blockage and death [20]. Thus, if the invading microorganism is susceptible to ROS, adaptation inside the plant does not take place, and the microorganism dies due to cell lysis or inability to replicate. However, some microorganisms are capable to metabolize and/or induce inactivation of the ROS function, resulting in plant tissue colonization and disease induction.

Several previous studies have shown that certain Xanthomonas proteins are involved in the adaptation to stress conditions [21-25]. Our group has been contributed to this knowledge by using a qualitative MudPIT strategy (Multidimensional Protein Identification Technology - protein chromatography followed by mass spectrometry) [26]. In that previously work it was shown that several differentially expressed proteins related to the Type II and III secretion systems and to Type IV pilus are key factors in initial stages of Citrus sinensis infection by Xac. Here our aim was to expand on the results of [26] by adopting a quantitative proteomic approach, coupling 2D gel technique to MALDI-TOF/TOF analysis. Our experimental set-up was designed to investigate the sequence of events related to adaptation of $X a c$ during $\mathrm{POB}$ in response to Xac infection in its compatible host, Citrus sinensis (L. Osbeck). We compared the protein profile in the early stages of infection (3 and 5DAI) with the profile under non-infectious conditions (NB medium) and with a medium that mimics plant conditions (XAM1), both for 24 h of growth. This comparative analysis identified a set of 124 differentially abundant proteins (up- and down-regulated). Through this analysis, it was possible to get a better understanding of Xac's adaptive process when in contact with the defense resources imposed by the plant during infection.

\section{Results and discussion}

Most of our results are based on 2D gel maps of Xac. The reference 2D gel maps of four protein extracts from Xac separated by 2D SDS-PAGE are shown in Fig. 1 (panels A to D). Panel A illustrates a representative 2D gel ( $\mathrm{pH} \mathrm{4-7} \mathrm{and} \mathrm{10-90} \mathrm{kDa)} \mathrm{with} \mathrm{separation} \mathrm{of} \mathrm{proteins}$ from Xac grown in NB medium (control condition). Panel B shows a representative 2D gel of proteins from Xac grown in XAM1, a medium without any plantderived molecules and which induces in vitro expression of factors related to pathogenicity and virulence $[27,28]$. This condition simulates 1DAI. Henceforth, references to 1DAI are used to mean expression levels observed for Xac growing in XAM1. Panels $\mathrm{C}$ and D show 2D gel maps obtained from proteins extracted from citrus leaves at 3DAI and 5DAI. 

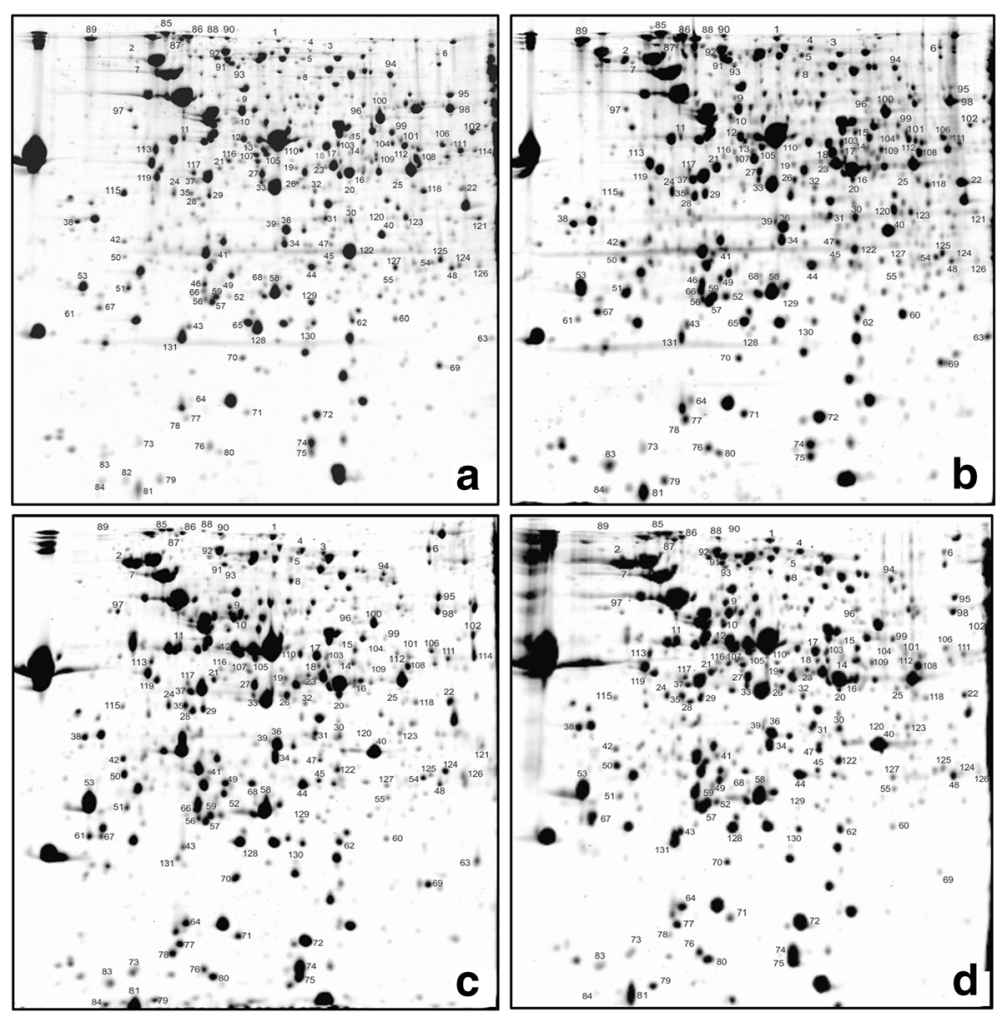

Fig. 1 Representative 2D proteome images of the Xac proteins. a Xac grown in nutrient broth (NB) medium. b Xac grown in inducing virulence medium (XAM1) for $24 \mathrm{~h}$, simulating 1DAl in plant. c Xac exudates from host citrus plants at 3DAl. d Xac exudates from host citrus plants at 5DAl. All samples were separated in $18 \mathrm{~cm}$ IPG strips across a linear $\mathrm{pH}$ range (4-7) using IEF in the first dimension and $12.5 \%$ SDS-PAGE in the second. Gels were stained with Coomassie blue. Numbers indicate the protein spots identified by mass spectrometry analysis (Tables 1 ). All experiments were done in triplicate

The image data analysis of triplicate $2 \mathrm{D}$ gels of each extract shows about 600 spots representing proteins. From the 600 spots, 220 were differentially abundant while under infectious conditions. Those spots whose expression value was greater than 1.5 -fold (or $1.5 \times$ ) relative to the control (as are all expression values mentioned from here on) were excised from the gel and identified by MALDI-TOF-MS/MS and database searching leading to the identification of 168 proteins in 157 spots. Among them, 124 spots with unique identification and statistically significant variation in intensity were detected: 79 were up-regulated proteins and 45 correspond to down-regulated proteins (Additional file 2). A comparative analysis of up-regulated proteins (green bars) and down-regulated proteins (red bars) in infectious conditions, classified by functional categories, is shown in Fig. 2a. Sixty-three out of the seventy-nine upregulated proteins $(\sim 80 \%)$ were manually grouped into six functional categories (the remaining proteins do not have an associated function). Likewise, 40 out of the 45 down-regulated proteins (89\%) were manually grouped into eight functional categories (Fig. 2b).
Some of these categorizations are summarized in Tables 1, 2, and 3, and an integrated illustration representing 62 differentially abundant proteins is shown in Fig.3. In what follows, we discuss these results in detail.

\section{Xac adaptation during interaction with plant tissue}

In this section, we present results for proteins that play a role in adaptation of Xac through Reactive Species depletion and osmotic adaptation (ROSd/OSM), OxideNitroreductases (REDOX), and iron acquisition and metabolism related proteins (IRON) that can contribute to its survival within plant tissues (Table 1). Together, the proteins related with this category comprise 10 of the 45 down-regulated proteins (22\%) and 27 of 79 upregulated proteins $(33 \%)$, which emphasize the importance of these proteins in the adaptive profile of Xac after $24 \mathrm{~h}$ of infection.

\section{Reactive oxygen species depletion}

KatG, SodM, GshB, Trx, TrxB, and BtuE proteins are directly involved in the metabolism and depletion of ROS, reducing the structural damage of bacterial DNA, 

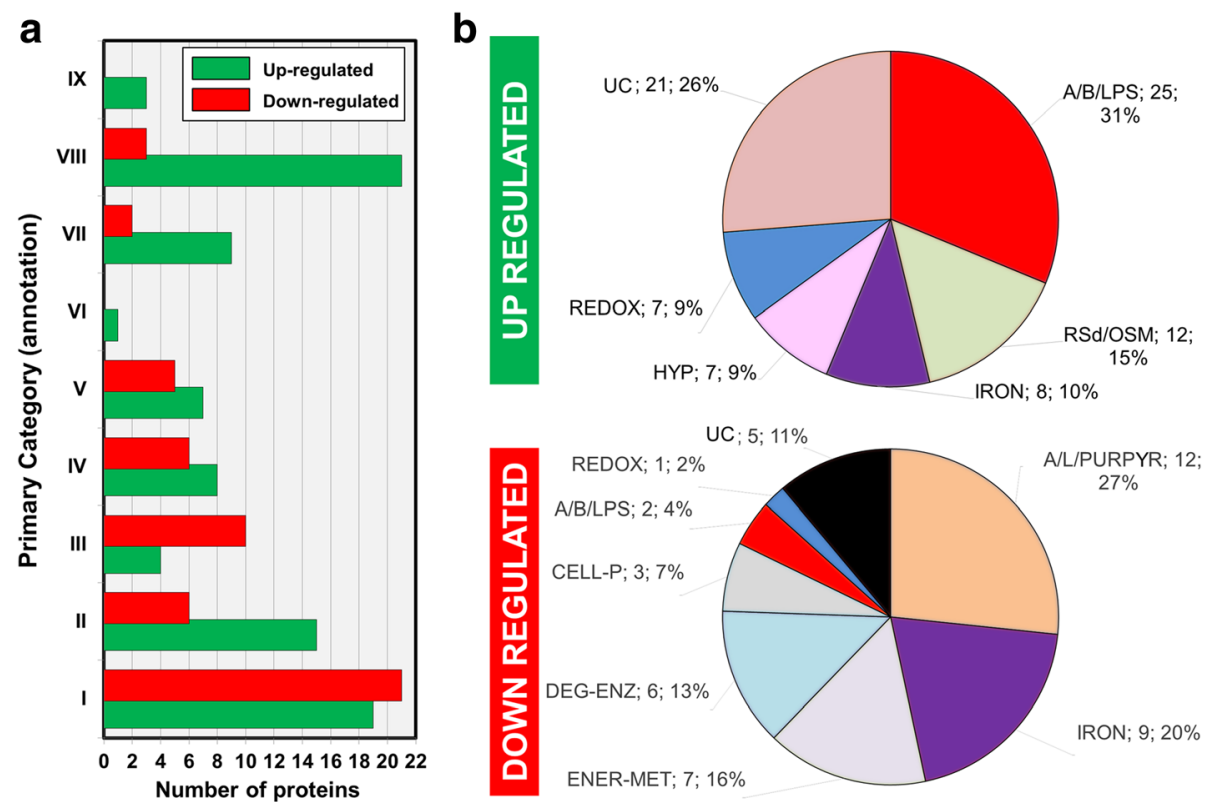

Fig. 2 Comparative analysis of functional protein profile of Xac under different conditions. a Comparison of differentially abundant proteins (up-regulated is shown in green and down-regulated in red) according to the categories used in the genome annotation [131]: I - Intermediary metabolism, II - Biosynthesis of small molecules, III - Macromolecule metabolism, IV - Cell structure, V - Cellular processes, VI - Mobile genetic elements, VII - Pathogenicity, virulence, and adaptation, VIII - Hypothetical, IX - ORFs with undefined category. b Differentially abundant proteins according to status of expression in infectious conditions and the number of proteins in each category. Three of these categories (A/B/LPS, IRON and REDOX) are common in both analyses. For details, check Table 1. Categories: A/B/LPS - Adhesion, biofilm, and LPS modulation; ROSd/OSM - Reactive species depletion and osmotic control; IRON - iron acquisition and metabolism; HYP - Hypothetical proteins; REDOX - Reduction and oxidation related proteins; UC - Uncharacterized class; A/L/PURPYR - Amino acids, lipids, purines and pyrimidines metabolism; ENER-MET - Energy metabolism; DEG-ENZ Degrading enzymes; CELL-P - Cellular process

proteins and lipids. The importance of these enzymes in the adaptive process of Xanthomonas, avoiding programmed cell death for example, has been previously described [21-23, 29]. We observed that SodM and KatG were up-regulated in all experimental conditions. However, the expression of KatG increases progressively and reaches a peak value (35x) at 5DAI. In this context, it is worthwhile to point out that recent studies have shown that mutation in katG gene (XAC1301) leads to a massive reduction of virulence in Xanthomonas [24]. This gene is also involved in tumor development induced by Agrobacterium tumefaciens in Kalanchoe plants [30] and has been described as a key component in Erwinia crysanthemi virulence induction process [31]. Additionally, thioredoxin ( $\operatorname{Trx})$ and thioredoxin reductase (TrxB), together with glutathione-glutaredoxin, which control ROSs concentration by reducing disulfide bonds [32], showed differential expression levels. These values (0.99 to 2.93 times up) were relatively low when compared to those of other analyzed proteins, but the values remained relatively stable from 1DAI to 5DAI. Glutathione synthetase (GshB) and glutathione peroxidase (BtuE) were also up-regulated while BtuE showed high levels of expression at 1DAI $(24 \times)$ and 5DAI (13×).

\section{Osmotic adaptation and oxide-Nitroreductases}

Concerning the mechanism of organic peroxides, Ohr and OsmC proteins are part of the depletion of this mechanism in bacteria. Ohr, primarily described in Xanthomonas, is expressed in the presence of organic peroxides, but not under the influence of osmotic stress [33-36], while OsmC is induced only by osmotic stress and is controlled by a variety of regulators responsive to stress [37]. Our results demonstrate that OsmC has lower expression than $\mathrm{Ohr}$ in all conditions, but both increase over time, with Ohr reaching $24 \times$ at 5DAI. It is possible that the later expression of OsmC reflects not only the condition to which $\mathrm{Xac}$ is being exposed, but also the formation of alcohols resulting from Ohr catalysis [37]. Gsp protein was also detected as being upregulated. In other organisms Gsp has a key role in response to stress induced by tert-butyl hydroperoxide ( $\mathrm{tBOOH}$ - the organic peroxide), heat shock, acid $\mathrm{pH}$, detergents (bile salts, SDS), ethanol, sodium chloride, and $\mathrm{H}_{2} \mathrm{O}_{2}[38,39]$.

Regarding oxidoreductases and nitroreductases proteins, up-regulation of eight oxidoreductases and one nitroreductase in the same conditions were showed in our findings and also suggests a direct relationship 
Table 1 Differential expression of proteins in infectious conditions related to RS depletion, osmotic control, oxi-nitroreductases, and iron acquisition and metabolism

\begin{tabular}{|c|c|c|c|c|c|c|c|c|}
\hline SPOT & PROTEIN & Product & Gene name & Expression & XAM1/NB & 3DAI/NB & 5DAI/NB & CLASS \\
\hline 2 & XAC2830 & TonB-dependent receptor & fhuA & Up & 62.06 & 144.00 & 148.00 & IRON \\
\hline 3 & XAC4368 & TonB-dependent receptor & fecA & Up & 0.00 & 8.99 & 3.16 & IRON \\
\hline 4 & XAC1301 & Catalase & katG & Up & 11.52 & 19.27 & 35.31 & $\mathrm{RSd} / \mathrm{OSM}$ \\
\hline 5 & XAC3201 & TonB-dependent receptor & fyuA & Up & 2.57 & 1.56 & 0.48 & IRON \\
\hline 6 & XAC2698 & $\begin{array}{l}\text { NADH-ubiquinone oxidoreductase, } \\
\text { NQO3 subunit }\end{array}$ & nuoG & Up & 5.21 & 13.89 & 1.78 & REDOX \\
\hline 7 & XAC2829 & Outer membrane hemin receptor & phuR & Up & 1.48 & 156.00 & 158.00 & IRON \\
\hline 20 & XAC1434 & $\begin{array}{l}\text { Nitrous oxidase accessory protein NosD, } \\
\text { contains tandem CASH domains }\end{array}$ & nos $D$ & Up & 13.37 & 54.21 & 13.10 & REDOX \\
\hline 25 & XAC4349 & Bifunctional oxireductase/alginate lyase & $\operatorname{algL}$ & Up & 2.79 & 0.12 & 3.43 & REDOX \\
\hline 26 & XAC0339 & Oxidoreductase & - & Up & 4.23 & 17.89 & 10.42 & REDOX \\
\hline 28 & XAC0288 & Oxidoreductase & mocA & Up & 42.40 & 27.05 & 10.87 & REDOX \\
\hline 30 & XAC4109 & Aerobic coproporphyrinogen III oxidase & hemF & Up & 3.23 & 0.24 & 1.70 & $\mathrm{RSd} / \mathrm{OSM}$ \\
\hline 31 & XAC2005 & Thioredoxin reductase & $\operatorname{tr} \times B$ & Up & 1.90 & 0.99 & 2.29 & $\mathrm{RSd} / \mathrm{OSM}$ \\
\hline 32 & XAC3103 & Glutathione synthetase & $\operatorname{gsh} B$ & Up & 1.09 & 0.61 & 2.75 & $\mathrm{RSd} / \mathrm{OSM}$ \\
\hline 35 & XAC4009 & Arginase & $\operatorname{argl}$ & Up & 1.34 & 8.41 & 11.58 & $\mathrm{RSd} / \mathrm{OSM}$ \\
\hline 38 & XAC2783 & Thioredoxin & $\operatorname{tr} x$ & Up & 2.93 & 1.89 & 2.42 & $\mathrm{RSd} / \mathrm{OSM}$ \\
\hline 45 & XAC2936 & ABC transporter ATP-binding protein & ynhD & Up & 1.04 & 4.60 & 4.37 & IRON \\
\hline 48 & XAC1160 & Oxidoreductase & $b d c A$ & Up & 0.33 & 0.31 & 2.58 & REDOX \\
\hline 53 & XAC3664 & Outer membrane protein & ompW & Up & 2.28 & 4.08 & 3.36 & IRON \\
\hline 58 & XAC2386 & Superoxidase dismutase & sodM & Up & 1.45 & 1.84 & 1.75 & $\mathrm{RSd} / \mathrm{OSM}$ \\
\hline 60 & XAC0554 & Nitroreductase & -— & Up & 22.22 & 0.56 & 0.53 & REDOX \\
\hline 61 & XAC1149 & Bacterioferritin & $b f r$ & Up & 23.71 & 155.00 & 0.00 & IRON \\
\hline 62 & XAC3123 & Starvation-inducible DNA-binding protein & $d p s$ & Up & 2.07 & 2.70 & 3.04 & IRON \\
\hline 64 & XAC2369 & General stress protein & $g s p$ & Up & 6.00 & 88.95 & 117.14 & RSd/OSM \\
\hline 66 & XAC4346 & Glutathione peroxidase & btuE & Up & 24.25 & 1.73 & 13.30 & $\mathrm{RSd} / \mathrm{OSM}$ \\
\hline 67 & XAC2932 & Protease & $p f p l$ & Up & 6.09 & 11.82 & 14.43 & $\mathrm{RSd} / \mathrm{OSM}$ \\
\hline 74 & XAC2915 & Osmotically inducible protein & osmC & Up & 0.95 & 2.89 & 2.89 & RSd/OSM \\
\hline 75 & XAC0282 & Organic hydroperoxide resistance protein & ohr & Up & 5.30 & 19.40 & 24.36 & $\mathrm{RSd} / \mathrm{OSM}$ \\
\hline 85 & XAC2743 & Oar protein & oar & Down & 1.81 & 0.34 & 0.72 & IRON \\
\hline 86 & XAC4274 & OmpA-related protein & - - & Down & 1.66 & 0.27 & 0.43 & IRON \\
\hline 87 & XAC4273 & OmpA-related protein & -— & Down & 1.69 & 0.05 & 0.88 & IRON \\
\hline 88 & XAC2742 & TonB-dependent receptor & btuB & Down & 0.00 & 0.00 & 0.05 & IRON \\
\hline 89 & XAC3444 & TonB-dependent receptor & btuB & Down & 1.78 & 0.00 & 0.00 & IRON \\
\hline 91 & XAC0823 & Outer membrane hemin receptor & phuR & Down & 1.17 & 0.00 & 0.00 & IRON \\
\hline 92 & XAC0176 & Ferripyoverdine receptor & fpvA & Down & 0.00 & 0.09 & 1.20 & IRON \\
\hline 93 & XAC3498 & $\begin{array}{l}\text { Outer membrane receptor for ferric iron } \\
\text { uptake }\end{array}$ & fhuE & Down & 0.40 & 0.05 & 0.40 & IRON \\
\hline 111 & XAC3802 & $\begin{array}{l}\text { Fe-S oxidoreductase, related to } \\
\text { NifB/MoaA family }\end{array}$ & -— & Down & 0.12 & 0.15 & 0.07 & REDOX \\
\hline 128 & XAC3354 & Outer membrane protein $\mathrm{W}$ & ompW & Down & 0.00 & 0.00 & 0.00 & IRON \\
\hline
\end{tabular}

${ }^{a}$ Also present at A/B/LPS Class

between iron homeostasis and stress [40]. Among oxidoreductases, MocA showed increasing expression under the conditions studied reaching the peak value of $42 \times$ at
1DAI, the same expression profile of a nitroreductase coded by XAC0554 that was up-regulated $22 \times$ at 1DAI. The proteins encoded by XAC0339, XAC2698 (NuoG), 
Table 2 Differential expression of proteins in infectious conditions related to adhesion, biofilm, and LPS biosynthesis

\begin{tabular}{|c|c|c|c|c|c|c|c|c|}
\hline SPOT & PROTEIN & Product & Gene name & Expression & $\mathrm{XAM} 1 / \mathrm{NB}$ & 3DAI/NB & 5DAl/NB & CLASS \\
\hline 1 & XAC1882 & Aconitase & $r p f A$ & Up & 5.71 & 6.92 & 7.59 & $\bar{A} / B / L P S$ \\
\hline 8 & XAC3239 & Pilus biogenesis protein & pilB & Up & 1.48 & 4.33 & 9.39 & $\mathrm{~A} / \mathrm{B} / \mathrm{LPS}$ \\
\hline 9 & XAC3300 & Lipase & estA & Up & 1.93 & 21.98 & 96.64 & $A / B / L P S$ \\
\hline 11 & XAC3579 & Phosphoglucomutase & $x a n A$ & Up & 0.19 & 3.91 & 7.29 & $\mathrm{~A} / \mathrm{B} / \mathrm{LPS}$ \\
\hline 13 & $\begin{array}{l}\text { XACb0007 } \\
\text { XAC3225 }\end{array}$ & $\begin{array}{l}\text { Lytic mureintransglycosylase } \\
\text { Transglycosylase }\end{array}$ & $\begin{array}{l}m / t \\
m l t B\end{array}$ & Up & 8.11 & 71.06 & 113.00 & $A / B / L P S$ \\
\hline 17 & XAC3602 & Cystathionine gamma-lyase-like protein & metB & Up & 0.00 & 2.67 & 12.91 & $A / B / L P S$ \\
\hline 18 & XAC2504 & Regulator of pathogenicity factors & $r p f N$ & Up & 354.75 & 6.19 & 13.17 & $A / B / L P S$ \\
\hline 21 & XAC3456 & 3-isopropylmalate dehydrogenase & leuB & Up & 43.75 & 7.62 & 18.57 & $A / B / L P S$ \\
\hline 22 & XAC1017 & $A B C$ transporter sulfate binding protein & $s b p$ & Up & 45.65 & 13.96 & 1.78 & $A / B / L P S$ \\
\hline 23 & XAC0656 & Rod shape-determining protein & mreB & Up & 0.96 & 3.08 & 8.57 & $A / B / L P S$ \\
\hline 25 & XAC4349 & Bifunctional oxireductase/alginate lyase & $\operatorname{algL}$ & Up & 2.79 & 0.12 & 3.43 & $A / B / L P S$ \\
\hline 33 & XAC0785 & $\begin{array}{l}\text { UDP-3-O-[3-hydroxymyristoyl] } \\
\text { N-acetylglucosamine deacetylase }\end{array}$ & IpxC & Up & 1.33 & 0.27 & 2.48 & $A / B / L P S$ \\
\hline 34 & XAC3584 & Glucose-1-phosphate thymidylyltransferase & $r m / A$ & Up & 1.74 & 2.14 & 2.33 & $A / B / L P S$ \\
\hline 36 & XAC2292 & UTP-glucose-1-phosphate uridylyltransferase & galu & Up & 1.49 & 1.80 & 1.57 & $A / B / L P S$ \\
\hline 37 & XAC4219 & Lipid-binding SYLF domain & - - & Up & 30.72 & 20.18 & 8.09 & $A / B / L P S$ \\
\hline 40 & XAC3966 & Outer membrane lipoprotein SlyB & slyB & Up & 2.45 & 3.17 & 4.10 & $A / B / L P S$ \\
\hline 42 & XAC0623 & $\begin{array}{l}\text { Putative salt-induced outer membrane } \\
\text { protein YdiY }\end{array}$ & ydiY & Up & 6.83 & 8.70 & 1.38 & $A / B / L P S$ \\
\hline 43 & XAC0190 & Uncharacterized lipoprotein & - - & Up & 2.21 & 1.30 & 4.24 & A/B/LPS \\
\hline 44 & XAC0834 & Two-component system regulatory protein & COlR & Up & 1.58 & 2.01 & 2.50 & $\mathrm{~A} / \mathrm{B} / \mathrm{LPS}$ \\
\hline 49 & XAC3457 & 3-isopropylmalate dehydratase small subunit & leud & Up & 65.18 & 2.46 & 8.27 & $A / B / L P S$ \\
\hline 54 & XAC1028 & Phosphoglycerate mutase & pgmA & Up & 3.46 & 6.88 & 0.77 & $A / B / L P S$ \\
\hline 68 & XAC1344 & Cytoskeletal protein CcmA, bactofilin family & ccmA & Up & 1.89 & 9.49 & 8.66 & $A / B / L P S$ \\
\hline 77 & XAC0108 & Atse & atsE & Up & 9.99 & 22.76 & 27.21 & $A / B / L P S$ \\
\hline 78 & XAC1154 & Regulatory protein pilH family & pill & Up & _- & 1.00 & 1.00 & $A / B / L P S$ \\
\hline 81 & XAC3671* & $\begin{array}{l}\text { Uncharacterized conserved protein YajQ, } \\
\text { UPF0234 family }\end{array}$ & yajQ & Up & 8.74 & 84.52 & 0.19 & $A / B / L P S$ \\
\hline 123 & XAC1717 & 2-dehydro-3-deoxyphosphooctonate aldolase & $k d s A$ & Down & 0.51 & 0.06 & 0.07 & $A / B / L P S$ \\
\hline 129 & XAC2008 & $\begin{array}{l}\text { Outer-membrane lipoproteins carrier protein } \\
\text { precursor }\end{array}$ & IOIA & Down & 0.08 & 0.05 & 0.00 & $A / B / L P S$ \\
\hline
\end{tabular}

* putative hypothetical gene manually reannotated

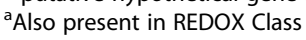

and XAC1434 (NosD) reached peaks at 3DAI (17.9x, $13.9 \times$, and $54,21 \times$ respectively) while the protein encoded by XAC3802 (Fe-S oxidoreductase) was downregulated in all stages of infection. Among the proteins annotated as having REDOX function, the most interesting is BdcA, encoded by the gene XAC1160. Although it has well conserved short chain dehydrogenase domain, the orthologous protein of BdcA in E. coli was characterized as Novel c-di-GMP-binding protein for biofilm dispersal [41]. Structurally, the protein presents a Rossmann nucleotide binding domain, hence the fact that it was annotated as an oxidoreductase, but unlike other proteins involved in binding and catalysis, c-di-GMP does not have the classic domains previously described for this function [42]. In this context, BdcA could also have function involved in signaling mediated by c-diGMP, which is important in adaptive processes of $\mathrm{Xac}$ inside the plant.

\section{Iron acquisition, internalization, and metabolism}

In addition to the above-mentioned proteins directly related to ROS depletion, proteins related to iron storage were seen to be also up-regulated. Bacteria synthesize proteins that are capable of storing iron under stress conditions to avoid Fenton reactions, controlling ROS generation [43]. This is the case for proteins Bfr and Dps, differentially abundant in all experimental conditions. While Dps showed differential expression similar 
Table 3 Expression profile of proteins in infectious conditions related to amino acids, lipids, purine-pyrimidine, and energy metabolism

\begin{tabular}{llllllll}
\hline Spot & PROTEIN & Product & Gene name & XAM1/NB & 3DAI/NB & 5DAI/NB & CLASS \\
\hline 90 & XAC1885 & Aconitate hydratase 2 & acnB & 0.02 & 0.50 & 0.03 & ENER-MET \\
99 & XAC0454 & Homogentisate 1,2-dioxygenase & hmgA & 0.14 & 0.00 & 0.17 & A/L/PURPIR \\
100 & XAC1533 & Dihydrolipoamide dehydrogenase & Idp & 0.98 & 0.61 & 0.95 & ENER-MET \\
101 & XAC3388 & Citrate synthase & gltA & 1.74 & 0.06 & 0.28 & ENER-MET \\
103 & XAC3688 & D-amino acid dehydrogenase subunit & dadA & 0.00 & 0.09 & 1.39 & A/L/PURPIR \\
108 & XAC2012 & 3-ketoacyl-coa thiolase & fadA & 0.78 & 0.49 & 0.86 & A/L/PURPIR \\
109 & XAC0265 & Acyl-coa dehydrogenase & acdA & 0.00 & 0.00 & 0.00 & A/L/PURPIR \\
113 & XAC0452 & 4-hydroxyphenylpyruvate dioxygenase & -1 & 0.00 & 0.13 & 0.43 & A/L/PURPIR \\
114 & XAC1348 & Acetoacetyl-coathiolase & atoB & 0.12 & 0.04 & 0.08 & A/L/PURPIR \\
115 & XAC3609 & Fumarylacetoacetate hydrolase & uptA & 0.07 & 0.04 & 0.04 & A/L/PURPIR \\
116 & XAC0445 & Pyruvate dehydrogenase E1 beta subunit & pdhB & 0.13 & 0.10 & 0.10 & ENER-MET \\
117 & XAC0902 & Transaldolase B & talB & 0.22 & 0.13 & 0.62 & ENER-MET \\
118 & XAC2916 & Aspartate carbamoyltransferase & pyrB & 0.62 & 0.08 & 0.06 & A/L/PURPIR \\
120 & XAC2502 & 1-phosphofructokinase (fructose 1-phosphate kinase) & fruK & 300.00 & 0.00 & 0.00 & ENER-MET \\
121 & XAC2715 & Acetyl-coenzyme A carboxylase carboxyl transferase & accD & 0.20 & 0.06 & 0.00 & A/L/PURPIR \\
122 & XAC2547 & Dihydrodipicolinate synthetase & dapA & 0.19 & 0.05 & 0.14 & A/L/PURPIR \\
124 & XAC1314 & Enoyl-coa hydratase & paaF & 0.24 & 0.09 & 0.35 & A/L/PURPIR \\
125 & XAC3586 & Electron transfer flavoprotein beta subunit & etfB & 0.73 & 0.05 & 0.09 & ENER-MET \\
127 & XAC3578 & IpsJ protein & ips//ipsJ & 0.21 & 0.08 & 0.16 & A/L/PURPIR \\
\hline
\end{tabular}

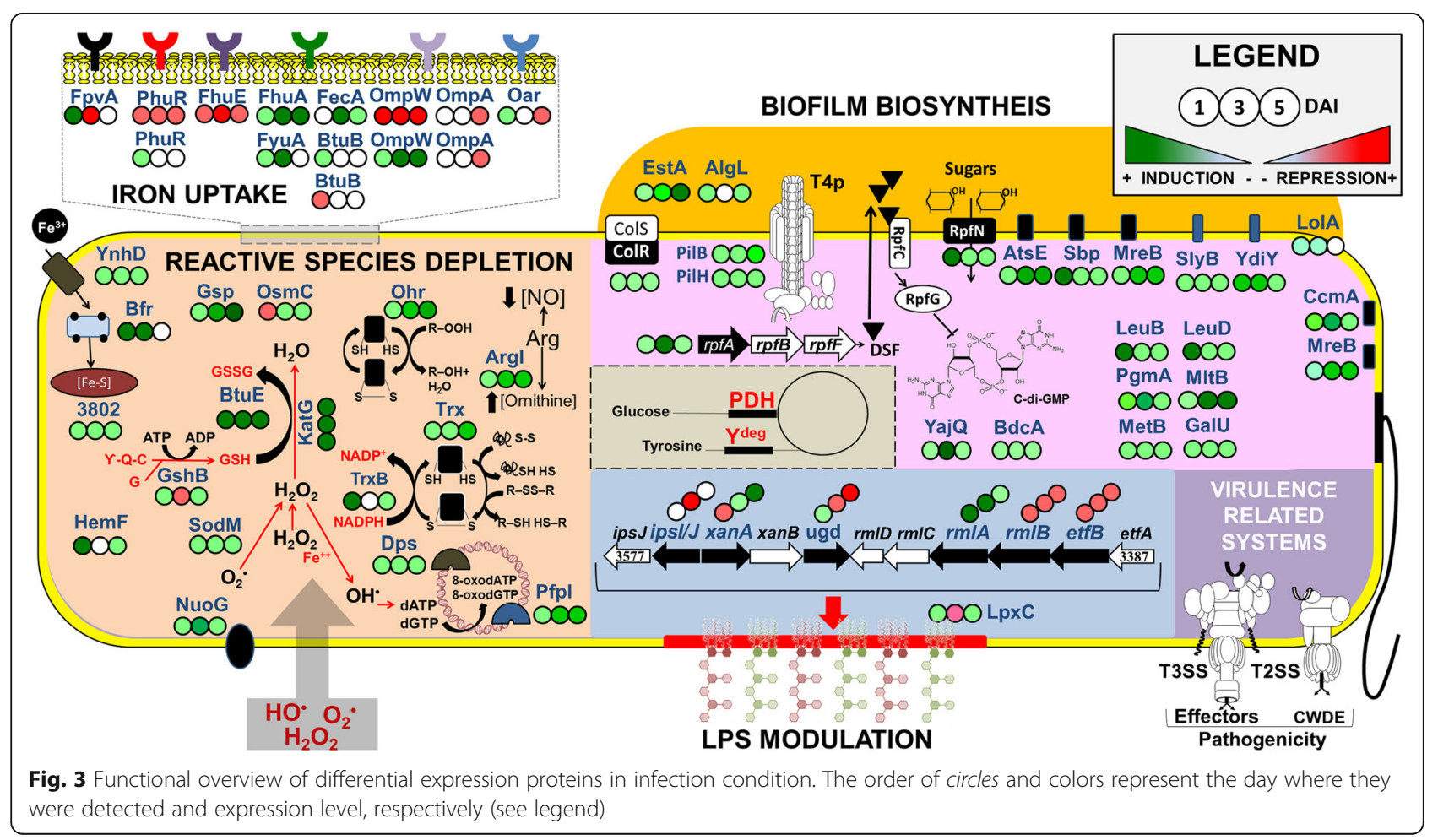


to most proteins associated with ROS depletion, Bfr showed a large differential expression value at 1DAI $(23 \times)$, with a peak of $155 \times$ at 3DAI, and then back to non-differentially expression levels at 5DAI. In fact, Dps has been characterized as a protein capable of storing about 500 atoms of $\mathrm{Fe}^{3+}$ in its central cavity [44], whereas Bfr is able to store about 1800 atoms of $\mathrm{Fe}^{3+}$, even though it binds to DNA [45]. Dps is also induced under carbonlimiting conditions or by the action of ROS being able to bind DNA to protect it from the action of oxidizing agents [46]. Under physiological conditions, in the absence of ROS, and in conditions of iron deficiency, these proteins help to maintain iron homeostasis. Thus, these proteins may reduce the rate of $\mathrm{Fe}^{2+}$ in the cellular environment, allowing the survival of Xac inside the plant [40].

Iron internalization proteins were found up-regulated in our infectious conditions. In an environment with high oxidative potential and high activity of Bfr and Dps in storing $\mathrm{Fe}^{3+}$, increasing internalization of this metal may compensate the lack of soluble Fe. This may explain the regulation of four distinct TonB-dependent receptors (TBDRs) possibly related to iron acquisition (FhuA, FyuA, PhuR, OmpW, and FecA) and one iron-regulated $\mathrm{ABC}$ transporter protein (YnhD). Except for FecA, upregulated only in direct contact with the plant at 3DAI and 5DAI, all other TBDRs were up-regulated also at 1DAI. PhuR, FhuA, and OmpW achieved expression peaks at 3DAI $(156 \times, 144 \times$, and $4.8 \times$ respectively), maintaining this level of expression also at 5DAI. Interestingly, while these six TBDRs were up-regulated, nine other proteins with related functions were down-regulated under the same conditions (FpvA, PhuR, BtuB $2 x$, Oar, OmpW, FhuE, and $\mathrm{OmpA}_{2 \mathrm{x}}$ ).

It is important to highlight that although TBDRs are classically related to internalization and iron metabolism, these proteins have been described as having some other functions such as internalization of carbohydrates [47]. Moreover, some TBDRs of $X$. campestris carrying a Carbohydrate Utilization Locus (CUT) are responsible for acquisition of carbohydrates derived from plants [48]. For Xac, a TonB-dependent transducer has been described as responsible for regulating pathogenicityrelated genes [49] (Additional file 3). These receptors might be able to bind to the same compound, but in different physiological conditions. In fact, no siderophore produced by Xac has been fully characterized yet, although biochemical tests have suggested its production [50]. Furthermore, a comparative proteomic study using 2D gels carried out on Xac [51] mature biofilm and planktonic cells showed that different TBDRs and OMPs are up- or down-regulated depending on the lifestyle of the organism, as observed for this work. The involvement of these proteins in the process and characterization of biofilm formation is well known. It is possible, therefore, that all of these TBDRs and OMPs that were shown here to be up- and down-regulated are also associated with cell adhesion and biofilm formation in conjunction with other proteins detected with this function in Xac during the infectious process (described below).

\section{Metabolism of related proteins}

Finally, some related proteins, as Argl that correspond to an arginase that protects Helicobacter pylori against acid stress, were explored in our discussion besides modulating colonization in mice. Arginase activity may also reduce the pool of arginine that could be converted to $\mathrm{NO}^{*}$ (nitric oxide) + citrulline by iNOS (inducible Nitric Oxide Synthase) [52]. Nitric oxide is a modulator of defense response in plants [53]. In our experiments, ArgI showed increased expression in all the experimental conditions analyzed, with a peak of $12 \times$ at 5DAI. Thus, it is possible that the increased expression of this protein in infectious condition could reduce the stress generated by the plant through reduction of $\mathrm{NO}^{\circ}$, a hypothesis previously put forward in a comparison of a virulent strain of Xylella fastidiosa (9a5c) with another non-virulent strain (J1A12) [54]. In that study, the authors suggested that the presence of this gene in the virulent strain could explain in part its success in colonizing the xylem tissue since the gene could reduce the plant defense response, which is different from what is observed in the nonvirulent strain not carrying this gene. In addition, HemF and PfpI stood out in our results as proteins associated with virulence and adaptation in stressful conditions. HemF is an aerobic coproporphyrinogen III oxidase, an enzyme responsible for the synthesis of protoporphyrin, which is a precursor in the synthesis of heme. Although up-regulated in all infectious conditions, HemF reached peak expression at 1DAI $(3.2 \times)$. In E. coli, synthesis of heme is observed when cytochrome and catalase syntheses occur [55]. HemF is one of the enzymes that require molecular oxygen to catalyze their reaction [56]. This protein was shown to be a member of the oxidative stress-induced regulon responsible for protecting cells from oxidative damage [57], which could explain why it has differential expression together with other proteins related to ROS adaptation, as described above. Similarly, the protease PfpI was up-regulated in all conditions with peak expression of $11 \times$ at 5DAI. PfpI is a member of DJ-1/Thij/PfpI superfamily, and plays a role in DNA protection under non-stress conditions. In a Pseudomonas aeruginosa pfpI-mutant strain, a dramatic increase of $\mathrm{H}_{2} \mathrm{O}_{2}$-induced damage was observed, besides biofilm formation changes [58]. Although not classically related to ROSd or REDOX function, ArgI, HemF, and PfpI seem to be crucial during the infectious process in response to $\mathrm{POB}$, and the loss of its functions could cause a disturbance in the adaptive process that would culminate in reducing virulence phenotypes. 


\section{Plant immune system evasion and protection against} stress induced by plant

The proteins grouped under adhesion, biofilm, and LPS synthesis (A/B/LPS) add to $25(31,6 \%)$ out of the 79 upregulated proteins and only $2(5 \%)$ out of the 45 downregulated proteins in infectious conditions, and are listed in Table 2.

\section{LPS synthesis and biofilm during virulence process}

Bacterial LPS and EPS are well described as being involved in plant pathogenesis [59]. LPS is the main component of the outer membrane in gram-negative bacteria, whose primary function is to maintain cell integrity against external agents. LPS is also fundamental in bacterial ecology for its role in mediating adhesion between bacteria or between bacteria and plant tissue. Besides acting as pathogenassociated molecular patterns (PAMPs), LPS constitutes the first layer in plant innate immunity induction and is referred to PAMP-triggered immunity in plants [60]. LPS is structurally divided into four parts: Lipid A, inner core, outer core, and O-antigen. Lipid A represents a hydrophobic moiety facing the outside of the outer membrane, allowing the LPS structure to be anchored, and is considered essential for growth and virulence of bacteria. Mutations in genes related to Lipid A synthesis are considered lethal, as it drastically alter the structure of this key component of membrane organization [61].

One of the differentially abundant proteins in this category was LpxC (a metalloprotease), involved with Lipid A biosynthesis. Some studies have focused on the use of inhibitors of LpxC and other proteins related to LPS biosynthesis as potential new antibiotics [62]. However, in the context reported in this paper, an up-regulation of this protein in infectious conditions (specially 5DAI) could be related to modulation of LPS structure in an attempt to ensure protection against bacterial stressinduced reduction during PTI response [63], as was described in P. aeruginosa [64].

Some of the genes involved in the synthesis of LPS and $\mathrm{O}$-antigen are inserted in tandem in a single genomic region in $X a c$ genome. This region can be represented by ipsJI-xanAB-ugd-rmlDCBA-etfBA-8CCSG-4XacSG-wzt$w z m-m e t B$ [65], where CCSG stands for Citrus Canker Specific Gene, which are genes found only in Xac, X. fuscans, $X a c^{*}$ and $X a c^{W}[66,67]$, and $X a c$ SG stands for Xac specific genes. One of the CCSGs is $n l x A$, and it has recently been characterized in Xac as essential for EPS and LPS synthesis, motility, biofilm formation, and resistance in the presence of peroxides during redox imbalance [68]. This emphasizes the importance of this whole region in the biology of Xac. RmlA is up-regulated in all experimental conditions [1DAI $(1.7 \times)$, 3DAI $(2.1 \times)$, and 5DAI $(2.3 \times)]$. This gene is inserted into the $r m l D C B A c l u s t e r$ involved in $\mathrm{O}$-antigen, which is important in structuring the bacterial cell as well as protecting against external action. In Stenotrophomonas maltophilia from Xanthomonadaceae family, mutations in the genes $r m l A, r m l C$, and $x a n B$ lead to a biofilm formation that presents differentiated characteristics [69]. It is noteworthy that $r m l B$, ugd, and ipsII, which are found in this large genome region are down-regulated in infectious conditions. This could be related to expression modulation of these proteins in early stages of infection analyzed in this study. MetB, encoded by the last gene of the cluster, corresponds to a cystathionine gamma-synthase protein $[66,70,71]$. In $X$. oryzae, met $B$ mutant showed colony morphologies of relatively reduced mucoidy, implying reduction of EPS productivity, beyond a loss of $\mathrm{O}$-antigen [72]. Furthermore, MetB presents a central role in cysteine, homocysteine, and methionine metabolism, which is essential for bacterial growth. Consequently, MetB has been identified as a potential drug target [73]. Finally, XanA (phosphoglucomutase) were up-regulated (3DAI $3.9 \times$ and 5DAI 7.3X) in infectious conditions. Together with $\mathrm{XanB}$, both proteins have been previously reported as essential to the process of xanthan gum synthesis [74], being responsible for the production of monomers of carbohydrates such as trehalose, which can play the role of an osmoprotectant [26].

Recently, Guo and colleagues found that GalU (XAC 2292) is essential to the formation of EPS and LPS in Xac, and that biofilm formation is reduced in the galu mutant strain $[75,76]$. Moreover, in Pseudomonas syringae this gene may change pathogen-host interaction, inducing PTI in tomato and preventing the survival of the pathogen inside the plant [77]. This is consistent with our finding that this protein is up-regulated in infectious conditions.

Alginate lyase (coded by XAC4349) catalyzes the degradation of alginate, a complex copolymer of $\alpha-\mathrm{L}$ guluronate, and its C5 epimer $\beta$-D-mannuronate was up-regulated at 1DAI $(2.8 \times)$ and 5DAI $(3.4 \times)$. The alginate structure protects LPS structure against stress in marine brown algae, Azotobacter vinelandii, Azotobacter chroococcum, and in several species of Pseudomonas [78-80]. Considering that the function of alginate lyase in $P$. aeruginosa is to detach cells from the surface, so they may spread and colonize new sites [81], it is possible that in Xac this enzyme functions to avoid competition with other bacteria that produce alginate within the plant [82], leading to more susceptibility to the action of this stressful condition imposed by plant during infection. Alternatively, alginate lyase may modulate the structure of their LPS and regulate the induction of plant innate immunity [83]. Thus, like AtsE, a more detailed study of the functionality of alginate lyase is necessary for a better understanding of its role in the mechanism of plant-pathogen interaction.

Concerning biofilm formation, Sbp is encoded by the first gene of an operon (XAC1017-1020) associated to 
an $\mathrm{ABC}$ transporter. This protein was also up-regulated in infectious conditions, reaching $45.6 \times$ at $1 \mathrm{DAI}$, and then decreasing to $13,9 \times$ and $1,8 \times$ at 3 and 5DAI respectively. When Sbp is mutated, it leads to reduced biofilm formation in Xac [84]. In fact, biofilm formation is a key component in the pathogenicity process of Xac. In Listeria and Rhizhobium a link between loss of the homolog gene and decrease in biofilm has also been shown $[85,86]$.

Type IV pilus (T4P) correspond to an important structure found on the surface of filamentous bacteria during adhesion, and they are involved in twitching motility and other activities such as bacterial surface adherence, biofilm formation, colonization, genetic material uptake, and virulence [87]. PilB is involved in pilus assembly (extension/polymerization) and acts as a motor responsible for twitching motility together with PilT. Mutations in PilB stop completely T4P formation [88], and a mutation in Xylella fastidiosa homolog gene disabled twitching and inhibited the bacteria from colonizing upstream vascular regions in plants [89]. On the other hand, the same mutation did not affect attachment to polysaccharides present in insect mouth nor foregut extracts [90]. PilH, characterized as a regulatory gene, when mutated leads to a reduced swarming and significant change in biofilm formation in Pseudomonas aeruginosa [91]. The differential expression of these T4P proteins under infectious conditions observed in our results combined with the results cited in the literature suggest that these proteins are probably important to colonization, displacement favored via swarming, and biofilm formation. No significant differential expression of PilH was detected. However, for PilB it was observed differential expression at 3DAI $(4.3 \times)$ and 5DAI $(9.4 \times)$.

MreB is a protein involved in cell shape in rod-shaped bacteria. Patch motility is largely powered by cell-wall synthesis, and MreB polymers may restrict diffusion of patch components in the membrane and orient patch motion [92]. MreB regulates production, location, and function of T4P in Pseudomonas aeruginosa, and is therefore fundamental to the process of biofilm-mediated colonization [93]. This may be linked with the concomitant differential expression of PilB mentioned above. In our study both proteins MreB and PilB have very similar expression profiles and levels suggesting that MreB may regulate PilB expression also in Xanthomonas.

Phosphoglycerate mutase (PgmA) participates in the bacterial energy metabolism (glycolysis and gluconeogenesis), but some studies have suggested its role in biofilm formation [94, 95]. It has also been described as critical to the process of virulence induced by other pathogens [96]. We observed PgmA to be up-regulated in all infectious conditions [1DAI $(3.5 \times)$, 3DAI $(6.9 \times)$, 5DAI (0.77)].

\section{Adhesion and virulence induction}

Regarding attachment to host cells, AtsE coded by XAC0108 is a protein required for adhesion. In Agrobacterium tumefaciens, AtsE is inserted in the chromosome region containing genes required for virulence and attachment to host cells [97]. Homologs occur in all genera belonging to Xanthomonadaceae family except in Xylella (data not shown).

During infection, the virulence induction is a key process that allows tissue colonization. The rpfA gene is involved in synthesis and cell signaling mediated by diffusible signal factor (DSF), which modulates quorum sensing in bacteria from Xanthomonadaceae family. $\mathrm{Mu}$ tation in the regulator of pathogenicity factors genes (rpfA-I) decrease virulence of such bacteria [98]. Furthermore, RpfA acts as an aconitase and is therefore essential for iron homeostasis [99, 100]. In our experiments, RpfA was up-regulated in all experimental conditions reaching a peak of differential expression at 5DAI $(7 \times)$. By contrasting the period of RpfA expression, it is possible to highlight the RpfN protein, which showed the highest peak of expression at 1DAI (350x), reducing to $6.12 \times$ and $13.17 \times$ in later times respectively. RpfN is a sugar-selective porin in $X$. oryzae (Xoo) according to UniProt/EMBL [101]. Mutation in $r p f N$ increases synthesis of polygalacturonate lyase [99], which induces degradation of plant cell wall. In Burkholderia pseudomallei, OprB protein, homologous to $\mathrm{RpfN}$, was shown to be important for biofilm formation [102], and more recently RpfN has been shown to be up-regulated under physiological conditions when Xac biofilm is produced [51]. These findings suggest that increasing synthesis of degradation enzymes may increase the supply of substrates in contact with plant tissue, compensating the lack of sugar caused by the mutation.

The gene encoding Mlt (XACb0007), a transglycosylase protein, is located in the pXAC64 plasmid in a region of $7260 \mathrm{bp}$. A gene with $95 \%$ of sequence similarity ( $m l t B$ - XAC3225) can be found in the chromosome. This region in the plasmid is flanked downstream by $x o p E 2$, while the same region on the chromosome is flanked upstream by $x o p E 3$ and downstream by xopA1 [66]. All these Xop proteins are known to be T3SS effectors [103] and therefore directly related to virulence induction in Xanthomonas. Interestingly, mlt/mltB show similarity to hopA1 (a T3SS helper protein), which contributes to translocation of T3SS effectors [104]. Mutation in the chromosomal copy of this gene led to a complete loss of Xac virulence in its compatible host [105]. More recently, Ferreira and co-authors [106] showed that the plasmid copy of $m l t B$ gene carried by Tn3-like ISXax2 was indeed functional and required to generate symptoms in plant. The authors also showed that MltB, type III secretion system effector protein 
(T3SEs), and transcription activator-like effectors (TALEs) are strictly related to the emergence of virulence and pathogenesis. Furthermore, it was also demonstrated that the transposase ISXax2 and associated mobile insertion cassettes (MICs) probably act as key agents in spread and modulation of bacterial virulence and host-specificity in this group of plant pathogens. Thus, up-regulation of Mlt/MltB in infectious conditions appears to have a direct correlation with effector secretion and virulence induction, which could validate its function based on sequence similarity with hopA1. It is important to highlight that this was the protein that showed the highest differential expression, increasing along the infectious process: 1DAI $(8 \times)$, 3DAI $(71 \times)$, and 5DAI $(113 \times)$.

EstA is an esterase described as fundamental to the process of virulence of some pathogens, being essential to promote colonization of host tissue [107]; and it was also up-regulated, with $6 \times$ at 1 DAI and $97 \times$ at 5DAI. In $P$. aeruginosa, this lipase binds to alginate increasing enzyme stability and accumulation of lipase in EPS [79]. Mutation in this gene in $X$. oryzae led to reduced virulence of the pathogen in rice [71], and this proteins has been described as enzyme targeted for biochemical identification of pathogenic strains of Xanthomonas [108].

ColR and ColS act together as a two-component regulatory system, representing the regulatory and sensing units respectively. In Xac, there are three copies of this system (XAC0834-35, XAC1221-22, and XAC325049). Recently, studies have revealed the importance of this dual component system in pathogenicity of Xac [109], as well as a component required for virulence and growth in iron-limiting conditions in Xoo [110]. Thus, up-regulation of ColR under infectious conditions [1DAI $(1.6 \times)$, 3DAI $(2 \times)$, 5DAI $(2.5 \times)$ ] may have two fundamental roles: one as a protein that participates in biofilm synthesis, and the other as a protein that takes part in the Fe deficiency-induced oxidative condition imposed by plants.

LeuB and LeuD, encoded by part of a gene cluster $($ leuABDC), are involved in valine, leucine, and isoleucine biosynthesis. They were up-regulated in all conditions, but it was on conditions that simulates 1DAI that their expressions were highlighted, $43 \times$ and $65 \times$ respectively to LeuB and LeuD. Mutation in leuB in Xac led to reduced Xac virulence in the compatible host [105]. Likewise, mutation in leuD in Pseudomonas savastanoi pv. savastanoi resulted in massive virulence reduction in Olea europaea plants [111]. Thus, this whole cluster may play a critical role in the process of plant-pathogen interaction.

Although it has been previously annotated as a hypothetical protein, the protein encoded by the gene XAC3671 actually corresponds to YajQ protein. In a recent study in $X$. campestris it was demonstrated that YajQ belongs to a new class of effector binding proteins of c-di-GMP which contributes to virulence induction [112]. Finally, five other proteins previously annotated as hypothetical were included in this functional category after analysis of its COGs and reannotation; all of them were up-regulated during the infectious process. XAC3966 and XAC0190 encode membrane lipoproteins with similar expression profiles. XAC0623 is a saltinduced putative outer membrane protein (YdiY) with expression peak at 1DAI $(6,83 \times)$ while XAC4219 corresponds to a protein with a lipid-binding SYLF domain. The last and most interesting is the protein encoded by XAC1344, which corresponds to a cytoeskeletal protein $(\mathrm{CcmA})$. These proteins are associated with cell motility, cell morphology, and cell division since they are members of bactofilin family [113]. In M.xanthus, bactofilin BacP interacts with PilB and PilT (previously described and up-regulated), which are responsible for extension and retraction of $\mathrm{T} 4 \mathrm{p}$ respectively, and thus for the motility of the cell [114]. In a comparative proteome study between wild type strain and a mutant strain for hrpB gene, Zimaro and collaborators demonstrated that $\mathrm{CcmA}$ is one of the proteins suppressed in the mutant strain evidencing a possible relationship between type III secretion system and motility in Xac [51], as previously reported in other model organisms [115].

\section{Energy metabolism and metabolism of amino acids, lipids, and purine-pyrimidine}

The energetic metabolism is a crucial process to ATP and NADH/NADPH generation. Under specific conditions, as in case of redox imbalance, some metabolic alterations are important for bacterial fitness, as it is for the antioxidant process maintenance. Our results indicate that some enzymes related to glycolysis, transport chain reaction, and oxidative phosphorylation are upregulated (Additional file 4: Figure S2, Table 3).

On the other hand, TCA cycle proteins were downregulated, in particular the crucial enzymes for pyruvate conversion to Acetyl-CoA. Some recent results have shown that pyruvate secretion and TCA cycle deregulation are crucial for pathogenicity in some bacteria [116], which is consistent with our findings [117]. However, in Xac such connections have not been shown until now.

Interestingly, our results also indicate that three out of five proteins that participate in tyrosine conversion to fumarate were down-regulated: 4-hydroxyphenylpyruvate dioxygenase (XAC0452), HmgA - homogentisate 1,2-dioxygenase (XAC0454), and UptA - fumaryl acetoacetate hydrolase (XAC3609) (Additional file 4). While investigating the protein expression profile of $P$. aeruginosa in the presence of PQS (Pseudomonas Quinolone Signal), Bredenbruch and colleagues observed repression of two 
homologous proteins (PA2008-FahA and PA2009HmgA) with concomitant up-regulation of a series of proteins involved in redox process response [118]. This is an indication that oxidative stress and metabolism of tyrosine have some functional relationship. The role of PQS has also been investigated in cell-cell communication, quorum sensing, and iron entrapment to the balance for life and death decisions in Pseudomonas aeruginosa populations [119-121].

We observed that citrate synthase was down-regulated at 3DAI $(0.06 \times)$ and 5DAI $(0.28 \times)$. Even though it has been shown that citrate synthase is necessary for optimum levels of biofilm formation and virulence in Burkholderia cenocepacia [122], this protein could have been down-regulated by the absence of the substrate Acetyl-CoA, formed in the previous step by pyruvate dehydrogenase complex in Xac. For analogous reasons aconitase could also be suppressed in this case. It is important to note that aconitase have a Fe-S prosthetic group, and synthesis of this protein may be limited by oxidative conditions to which it is exposed.

\section{Hypothetical proteins}

In addition to eight hypothetical proteins that were reannotated, manually categorized and described in the previous sections (XAC3802, 1434, 1344, 4219, 3966, 0623, 0190, and 3671), five other proteins were reannotated based on COGs and included in the category of proteins with undefined category (UC): XAC0007, a putative Zndependent protease; XAC0193, a phosphohistidine phosphatase; XAC0381, a ketosteroid isomerase; XAC3140, a periplasmic TolA-binding protein; and XAC3851, an uncharacterized mettaloenzyme (YdcJ). All of them were up-regulated in infectious conditions. Thus, only seven proteins remained in the group of hypothetical proteins up-regulated in infectious conditions: XAC1093, 1364, 2246, 2315, 3680, 3866, and 3981 (Additional file 5).

In an attempt to understand the possible role of these hypothetical proteins in $\mathrm{Xac}$ metabolism, a clone library containing more than 10,000 Xac mutants previously described was analyzed in an attempt to find a mutant for these hypothetical genes that would reduce the virulence in Citrus plants [105]. Only one of these mutants (DXAC3981) did not seem to cause any symptoms throughout the infectious process (14 days of observation when inoculated in compatible hosts (Citrus sinensis and Citrus limonia) (Fig. 4). In vivo growth curve of bacteria showed that this gene appears to be essential for the adaptive process of Xac during the infectious process. The Tn-insertion in XAC3981 likely disrupts expression of XAC3982 and XAC3983 since these genes are predicted to form an operon [123]. Although the colony count curves are still valid, we cannot affirm that the mutation of XAC3981 is responsible for virulence reduction phenotype, but rather the combined function of the operon.

The gene $h t r A$ encoding a protease DO (XAC3980) is located upstream of gene XAC3981, whose mutation results in complete absence of symptoms [105]. In addition, there are two hypothetical proteins (XAC39823983) downstream of XAC3981, which together with XAC3981 are found only in bacteria from Xanthomonadaceae family (Additional file 6), and in the same order (i.e. syntenic) according to STRING [124]. In X.
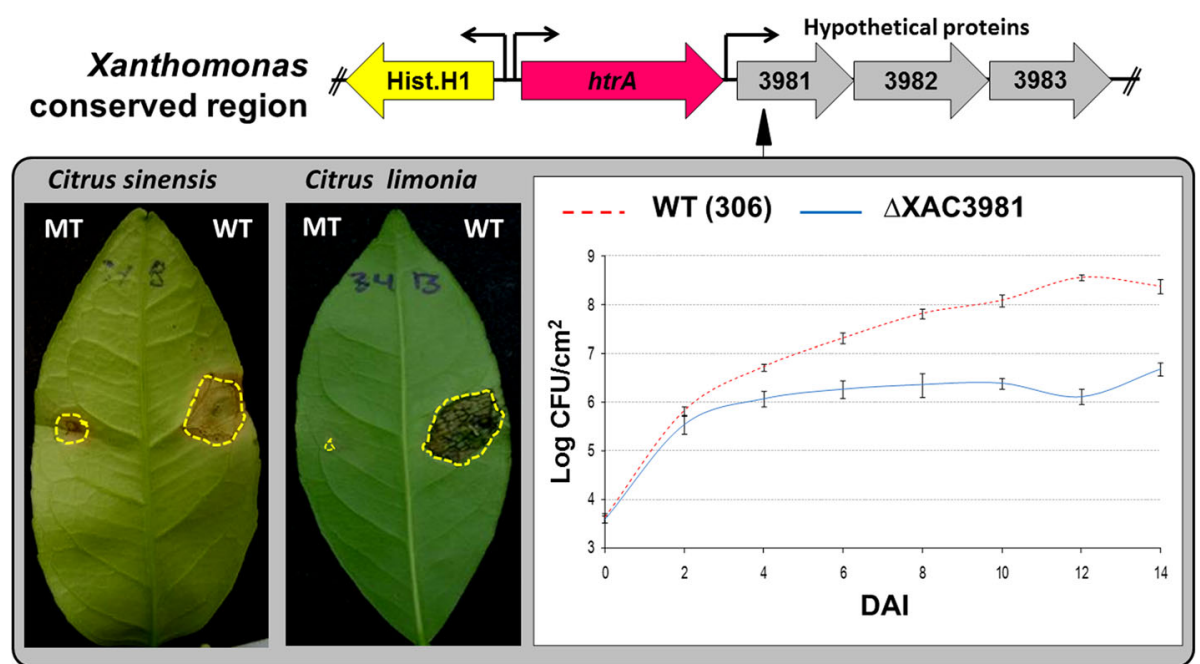

Fig. 4 Analysis of the phenotypic profile of virulence in the mutant XAC3981, located in a putative operon with XAC3982 and XAC3983 genes (gray arrows). The mutant XAC3981 led to a marked reduction in the virulence phenotype in both Citrus sinensis and Citrus limonia after 14DAl. The growth curve of the mutant in vivo showed less bacterial titration along the infectious process, which could explain the absence of observed phenotypes. This mutated gene is flanked by htrA (upstream), and by two hypothetical proteins (downstream) whose orthologous pairs were found only in bacteria of c (See Additional file 6: Figure S4) 
oryzae strains this region appears as a single operon according to OperonDB [123], and it is adjacent to a downstream group of genes encoding Hrp proteins, more specifically a HrpF peninsula [125].

Although it cannot be classified as a putative pathogenicity island since does not show any classic sign of being a product of horizontal gene transfer, this region may have been selected in a recent ancestor of Xanthomonadaceae and seems to be essential in maintaining the virulence process in bacteria of the genus Xanthomonas.

\section{An overview of the intricate adaptive mechanism of Xac inside plant}

Here we sketch a proposed scenario for the first five days of Xac infection based on the above results (Fig. 5). In the very first hours of infection, secretion system structural genes and effector genes are activated and the secreted proteins act on plant tissue, in order to overcome plant defenses and promote bacterial virulence [126] (Fig. 5a). At this point, we would also expect that proteins related to flagellum-depended motility and quorum sensing are also acting, which was not captured by our experiments because our observations started $24 \mathrm{~h}$ after infection. Once the plant detects the presence of the pathogen through specific PAMP receptors, the defense mechanisms are activated beginning massive production of oxygen reactive species such as superoxide (Fig. 5a) in POB. At this time, the infection could be controlled, or in case of compatible host the secondary defense response is induced by iron intracellular redistribution that promote the transcription of genes related to $\mathrm{H}_{2} \mathrm{O}_{2}$ production [127]. This in turn induces in $\mathrm{Xac}$ the expression of proteins directly related to ROS depletion, osmotic control, biofilm production, and iron acquisition and storage (Fig. 5b). At the same time, the pathogen modulates LPS synthesis through two different mechanisms. Lipid A modification is responsible for reducing the permeability of the outer membrane proteins to antimicrobial proteins, decreasing resistance responses from the host. In contrast, modification or loss of O-antigen leads to delay in recognition by the plant, allowing intracellular survival and protection against oxidative stress [128]. Together with LPS modulation, the expression of proteins related to adhesion, including OMP, and biofilm formation would increase protection against defenses by the plant $[129,130]$. Although the differentially abundant proteins were divided into distinct functional groups, our results suggest that this intricate network of proteins could be important in the adaptive process and defense against $\mathrm{POB}$ induced by host plants after $24 \mathrm{~h}$ of infection (Fig. 5c). The efficiency

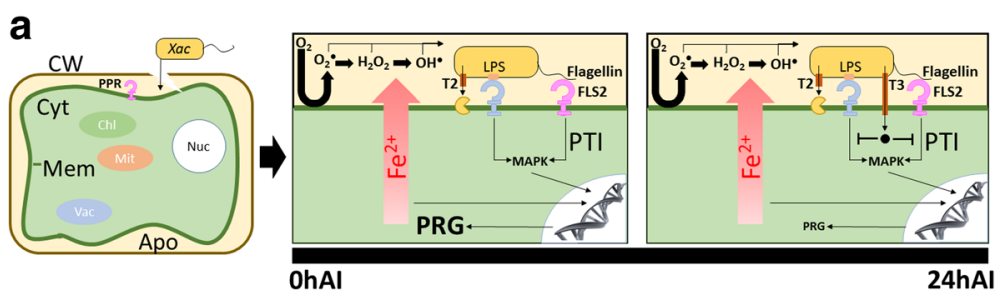

b

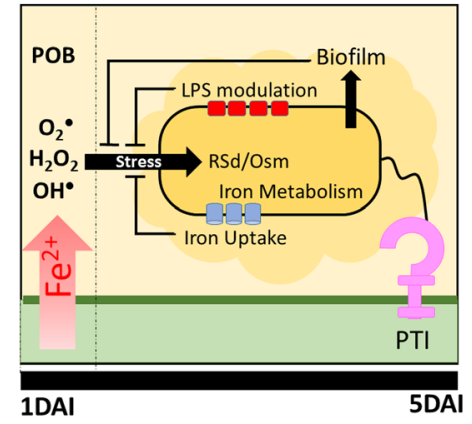

C

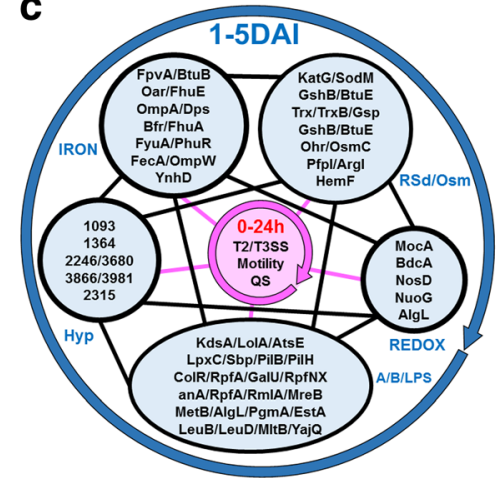

Fig. 5 Integrated outlook of proteins secreted between 1-5DAl. a During the first hours of infection, secretion system structural proteins, and proteins related with motility and quorum sensing are secreted. After recognition of PAMPs, a cascade of reactions culminates in the activation of PTI in order to avoid penetration of bacteria inside plant tissues increasing the ROS production during POB. Subsequently, Xac secretes effector proteins to overcome plant defenses and promote bacterial virulence. These processes may occur between 0 and $24 \mathrm{~h}$ after infection. b After $24 \mathrm{~h}$ of infection, Xac secretes higher amounts of proteins related with reactive species depletion and osmotic adaptation (ROSd/OSM), iron uptake and metabolism, biofilm formation, and LPS modulation in order to protect themselves against the stress caused by POB. c After activation of virulence related proteins during the first $24 \mathrm{~h}$ (pink), a protein repertoire involved in ROS depletion, EPS biosynthesis and LPS modulation, iron uptake and metabolism, and biofilm formation is active and working in an integrated manner between 1 and 5 DAl 
of all these processes described above would enable the pathogen to rapidly colonize, replicate, and disperse from the initial infection site to other tissues of the same plant or even to other citrus host plants, effectively triggering disease spread.

\section{Conclusions}

Our results provide the most complete repertoire of proteins active in the infectious process by $\mathrm{Xac}$ in a compatible host, adding substantially to what was previously known, in particular with respect to work published by some of us [26].We show that this repertoire is involved in ROS depletion, EPS biosynthesis and LPS modulation, iron uptake and metabolism, and biofilm formation, and that the component proteins work in an integrated manner. Previous studies have focused on classical virulence systems such as types II and III secretion systems (rpf genes); these systems are important for the pathogen to be able to start the infectious process, but they cannot ensure infection success by themselves. For the infection to be sustained other sets of proteins need to come into play, and these sets of encoded proteins were identified in this study. These proteins are primarily related to adaptation (defense) and damage to plant tissue (attack). Even though adaptation and induction of damage to plant tissue may seem unrelated biological processes, we believe that they are synergistic. Thus, the set of proteins identified in our study is associated with evasion of plant immune system increasing the antimicrobial resistance through protection against host defenses, improvement of intracellular survival, and protection against oxidative burst. In addition, through the expression of proteins related with iron uptake and metabolism, biofilm formation, and depletion of reactive species $X a c$ reduces the production of reactive species by the plant while intensifying production of biofilm and proteins related with reactive species depletion. Therefore, the proteins identified in our study are potential biotechnological targets for disease control since they seem to be essential for adaptation and survival inside plant tissues.

\section{Methods}

\section{Bacteria and culture conditions}

The Xac strain 306 pathotype A [131] used in this study was obtained from the culture collection of plant pathogenic bacteria at IAPAR (Instituto Agronômico do Paraná, PR, Brazil). This strain was grown at $28{ }^{\circ} \mathrm{C}$ in $\mathrm{NB}$ medium (Difco ${ }^{\mathrm{Tm}} \mathrm{NB}-5 \mathrm{~g} / \mathrm{L}$ peptone and $3 \mathrm{~g} / \mathrm{L}$ meat extract) with shaking at $200 \mathrm{rpm}$ for $24 \mathrm{~h}$, and was grown at $28{ }^{\circ} \mathrm{C}$ in XAM1 medium $\left(7.4 \mathrm{mM}\left(\mathrm{NH}_{4}\right)_{2} \mathrm{SO}_{4}\right.$; $16 \mathrm{mM} \mathrm{KH} \mathrm{PO}_{4} ; 30 \mathrm{mM} \mathrm{K} \mathrm{HPO}_{4} ; 1.6 \mathrm{mM}$ sodium citrate $\left(\mathrm{C}_{6} \mathrm{H}_{5} \mathrm{Na}_{3} \mathrm{O}_{7} .2 \mathrm{H}_{2} \mathrm{O}\right) ; 10 \mathrm{mM}$ fructose; $10 \mathrm{mM} \mathrm{su}$ crose; $1 \mathrm{mg} / \mathrm{mL}$ BSA; pH 5.4) with shaking at $200 \mathrm{rpm}$ for $24 \mathrm{~h}$. The cells were analyzed by spectrophotometer in $600 \mathrm{~nm}\left(\mathrm{OD}_{600}\right)$ at an optical density corresponding to the log phase (1.0).

\section{Plant inoculation}

'Pêra Rio' orange trees (Citrus sinensis L. Osbeck) were grown in a greenhouse for 4-6 months. Xac inoculum was prepared by cultivating the bacteria in solid NB medium at $28{ }^{\circ} \mathrm{C}$ for $16 \mathrm{~h}$ in order to obtain cellular mass. The cells grew to an optical density of $\mathrm{OD}_{600 \mathrm{~nm}}=1.0$, and then diluted with sterile distilled water to $\mathrm{OD}_{600 \mathrm{~nm}}=0.3\left(10^{8} \mathrm{CFU} / \mathrm{mL}\right)$. The suspension of cells was then used to infiltrate 50 young leaves by injection with a syringe without the needle, directly into the apoplastic space on the abaxial face of the leaves.

\section{Bacteria recovery from inoculated leaves}

Xac recovery was performed as described by Mehta and Rosato [132], with some modifications. The citrus leaves were excised from plants at 3 or 5DAI. The leaves were rinsed with $70 \%$ alcohol, sliced into small pieces using a sterile razor blade, and maintained for 20 min under agitation in sterile glass Becker containing $400 \mathrm{~mL}$ of cold $\left(4{ }^{\circ} \mathrm{C}\right)$ distilled water. After the incubation period, the exudate was centrifuged at $10,000 \mathrm{xg}$ for $10 \mathrm{~min}$ at $4{ }^{\circ} \mathrm{C}$ and the pellet containing the exudated $\mathrm{Xac}$ was used for protein extraction.

It is important to emphasize that 1DAI correspond to the bacteria cultivated in XAM1 media and 3 or 5DAI inoculated in plant.

\section{Protein extraction}

The extraction of total proteins was performed as described by Mehta and Rosato [132], with some modifications. Each Xac pellet was washed in phosphate buffer (1.24 g/L K $\mathrm{K}_{2} \mathrm{HPO}_{4} ; 0.39 \mathrm{~g} / \mathrm{L} \quad \mathrm{KH}_{2} \mathrm{PO}_{4} ; 8.8 \mathrm{~g} / \mathrm{L} \mathrm{NaCl}$, $\mathrm{pH}$ 7.2). Subsequently, the pellet was suspended in $0.75 \mathrm{~mL}$ of extraction buffer $(0.7 \mathrm{M}$ sucrose; $0.5 \mathrm{M}$ Tris$\mathrm{HCl}, \mathrm{pH} \mathrm{7} ; 30 \mathrm{mM} \mathrm{HCl} ; 50 \mathrm{mM}$ EDTA; $0.1 \mathrm{M} \mathrm{KCl}$, $40 \mathrm{mM}$ DTT) and incubated for $15 \mathrm{~min}$ at room temperature. The same volume of phenol was added. After $15 \mathrm{~min}$ of agitation, the suspension was centrifuged at $10,000 \mathrm{xg}$ and $4{ }^{\circ} \mathrm{C}$ for $3 \mathrm{~min}$, and the supernatant was recovered. This procedure was repeated twice. The proteins were precipitated with five volumes of $0.1 \mathrm{M}$ ammonium acetate in methanol, and the precipitate was washed once with $80 \%$ acetone. Protein concentrations were estimated by the Bradford method (Bio-Rad, Hercules, CA, USA).

\section{D-gel electrophoresis}

The precipitates (1 mg from each sample) were solubilized in $250 \mu \mathrm{L}$ of sample buffer (8 M urea, 2\% CHAPS, $70 \mathrm{mM}$ DTT, $0.001 \%$ bromophenol blue-BPB, $0.5 \%$ ampholytes of $\mathrm{pH} 4-7)$. First dimension was carried out 
in $13 \mathrm{~cm}$ strips (pH 4-7 linear gradient) in the IPG-Phor unit as described by the manufacturer (GE Healthcare). Precast IPG strip was focused in three steps $(500 \mathrm{~V}$ for $1 \mathrm{~h} ; 1000 \mathrm{~V}$ for $1 \mathrm{~h} ; 8000 \mathrm{~V}, 16,000 \mathrm{Vh})$. The temperature was maintained at $20{ }^{\circ} \mathrm{C}$. After isoelectric focusing, each strip was incubated for $12 \mathrm{~min}$ in $10 \mathrm{~mL}$ of $50 \mathrm{mM}$ Tris- $\mathrm{HCl}$ buffer $\mathrm{pH} 6.8,6 \mathrm{M}$ urea, 30\% v/v glycerol, $2 \% w / v$ SDS, $2 \%$ DTT, followed by a second incubation step in the same buffer solution, except that DTT was replaced by $2.5 \%$ iodoacetamide. Strips were then rinsed in Tris-glycine electrode buffer, transferred to homogeneous $12.5 \%$ SDS-PAGE and overlaid with $0.5 \% w / v$ agarose in running buffer containing BPB. Gels were run in a Hoefer SE600 system at $70 \mathrm{~V}$ for $10 \mathrm{~min}$ and $25 \mathrm{~mA} /$ gel for 7-8 h. A molecular mass marker ladder Mark12 ${ }^{\text {ma }}$ (Invitrogen) was used. The gels were fixed with $40 \%$ ethanol and 10\% acetic acid for $30 \mathrm{~min}$ and then stained with Coomassie Blue R 250 (SigmaAldrich), 0.025\% Coomassie Brilliant Blue, 40\% ethanol, $10 \%$ acetic acid, for $90 \mathrm{~min}$. All experiments were done in triplicate and first and second dimension gels were electrophoresed under identical conditions.

\section{Image and data analysis}

Direct scanning and image analysis was performed by MELANIE 2D gel analysis software (version 7.05). All experiments were done in triplicate to ensure reproducibility. Spots were quantified on the basis of their relative volume, that is, the spot volume divided by the total volume over the whole set of gel spots. The protein spots were manually confirmed. A 1.5 -fold change was set as criterion: only those spots with change in abundance of more than 1.5 -fold were taken into account. Differentially abundant protein spots were subjected to in-gel tryptic digestion and identified by mass spectrometry.

\section{In-gel digestion}

Protein spots were manually excised from the gels and washed with $25 \mathrm{mM}$ ammonium bicarbonate in 50\% acetonitrile overnight at room temperature to destain the proteins. The gel pieces were then dehydrated in $100 \%$ acetonitrile for $10 \mathrm{~min}$ and fully dried in a SpeedVac centrifuge (Savant, Minnesota, USA). Gel fragments were allowed to reswell in $10 \mu \mathrm{L}$ of the digestion buffer containing trypsin (Promega, modified sequencing grade) at a final concentration $10 \mathrm{ng} / \mu \mathrm{L}$ in $25 \mathrm{mM}$ ammonium bicarbonate. The gel fragments were digested with trypsin for $20 \mathrm{~h}$ at $37^{\circ} \mathrm{C}$. The resulting tryptic peptides were extracted from the gel pieces by incubating with $50 \mu \mathrm{L}$ of $50 \%$ acetonitrile in $5 \%$ trifluoroacetic acid twice for $15 \mathrm{~min}$, first with agitation and then with sonication. Supernatants were transferred, pooled, and concentrated to near dryness in a Speed-Vac centrifuge.
Each sample was then diluted with $10 \mu \mathrm{L}$ of Milli-Q water in $0.1 \%$ trifluoroacetic acid.

\section{MALDI-TOF/TOF analysis}

Roughly $0.4 \mu \mathrm{L}$ of the solution of extracted peptides was mixed with an equal volume of CHCA matrix solution (10 $\mathrm{mg} / \mathrm{ml}$-cyano-4-hydroxycinnamic acid (Aldrich, Milwaukee, WI) in $50 \%$ acetonitrile/0.1\% trifluoroacetic acid) and left to dry. Data for protein identifications were obtained from 4700 Proteomics Analyzer (Applied Biosystems, Foster City, CA). Both MS and MS/MS data were acquired with a neodymium-doped yttrium aluminum garnet (Nd:YAG) laser with a $200-\mathrm{Hz}$ repetition rate. Typically, 1600 shots were accumulated for spectra in MS mode while 2400 shots were accumulated for spectra in MS/MS mode. MS and MS/MS mass spectra were acquired in reflector mode and internally calibrated with trypsin autolysis peptides. Up to eight of the most intense ion signals with signal-to-noise ratio above 30 were selected as precursors for MS/MS acquisition. External calibration in MS mode was performed using a mixture of four peptides: des-Arg1-Bradykinin ( $\mathrm{m} / \mathrm{z}=$ 904.468), angiotensin I ( $\mathrm{m} / \mathrm{z}$ 1296.685), Glu1-fibrinopeptide B (m/z 1570.677), and ACTH (18-39) (m/z 2465.199). MS/MS spectra were externally calibrated using known fragment ion masses observed in the MS/MS spectrum of angiotensin I. MS/MS spectra were searched against the Xac genome data bank file downloaded from the NCBI, with 108,856 sequences; $41,308,596$ residues entries.

The mass spectrometry proteomics data have been deposited to the ProteomeXchange via MassIVE dataset submission workflow with the dataset identifier MSV000 080041.

\section{Database search}

All data were processed using the Data Explorer Software (Applied Biosystems, CA). Proteins were identified by correlation of tandem mass spectra and Xac genome data bank available at NCBI, using the MASCOT $^{\text {Tx }}$ software (Matrix Science, version 2.1). One missed cleavage per peptide was allowed and an initial mass tolerance of $0.05 \mathrm{Da}$ was used in all searches. Cysteines were assumed to be carbamidomethylated, and variable modification of methionine (oxidation) was allowed. To evaluate the false positive rate of this approach, a reversed sequence databank (a database in which the sequences have been reversed) containing the same number of proteins as in the Xac database was constructed. Identification was considered positive if it matched at least one unique peptide.

\section{Determination of differentially regulated proteins}

Proteins loaded on gels were normalized between replicates to partially quantify spot intensities and to 
minimize analytical variation among gels. To analyze protein intensity, triplicate 2D gels of the infected conditions were compared to control gels as well as to each other. At least 4 well-defined landmarks were used for matching gels: spots were quantified on the basis of their relative volume; spots a greater than 1.5 -fold change in their normalized volume between two sample groups were submitted for statistical analysis; spots that exhibited a statistically significant difference were selected for mass spectrometry identification, as well as those pertaining exclusively to one group (Additional file 7).

\section{Comparative genome/metabolism profile and hypothetical proteins reannotation}

BLAST [133] analysis was performed against the other Xanthomonas genomic sequences in the NCBI database to classify the hypothetical proteins differentially abundant. Metabolic pathways were obtained from KEGG (Kyoto Encyclopedia of Genes and Genomes) annotation database [134]. The hypothetical proteins were reannotated using information from COG database [135]. All these analyses were done by searches using the respective locus tag or by comparative sequences using the amino acids FASTA sequences.

\section{Mutant selection and in planta virulence phenotype analysis}

Among the hypothetical genes differentially expressed in infectious conditions only one gene mutated ( $\triangle \mathrm{XAC} 3981$ ) was selected from the Xac mutant library previously generated by Laia and collaborators [105]. The cellular concentration was adjusted using ${ }_{d d} \mathrm{H}_{2} \mathrm{O}$ to an optical density of 0.3 at $600_{\mathrm{nm}}\left(10^{8} \mathrm{CFU} / \mathrm{mL}\right)$. The $\triangle \mathrm{XAC} 3891$ and wild type strain suspension was infiltrated separately in two points of the left and right abaxial side of young 'Pera Rio' sweet orange (Citrus sinensis L. Osbeck) and Rangpur lime (C. limonia L. Osbeck) leaves, respectively. After inoculation, the plants (in triplicate) were grown in a chamber at $28{ }^{\circ} \mathrm{C}$ with artificial light photoperiod. The development of citrus canker symptoms in host plants was evaluated every day, from the $3^{\text {rd }}$ to the 14 st day after inoculation, and the symptoms were registered by digital photographs.

\section{In vivo growth curve}

The number of cells per leaf area was measured by means of a disk of $0.75 \mathrm{~cm}$ in diameter removed from inoculated leaves. The leaf disk was ground in $1 \mathrm{ml}$ of $1 \mathrm{mM} \mathrm{MgCl}_{2}$ solution, and serial dilutions $\left(10^{-1}\right.$ to $\left.10^{-7}\right)$ were prepared. A $10 \mu \mathrm{L}$ droplet of each dilution was deposited on the surface of solid TSA medium containing kanamycin. The plates were kept at $28{ }^{\circ} \mathrm{C}$ for $36 \mathrm{~h}$, and isolated colonies were counted. The experiment was repeated independently three times.

\section{Additional files} Additional file 1: Figure S1. Overview of Disease progression and
pathways involved at PII. (DOCX $736 \mathrm{~kb}$ )

Additional file 2: Table S1. Up and Down-regulated protein in infectious conditions. (DOCX $62 \mathrm{~kb}$ )

Additional file 3: Table S2. Profile of TonB receptors Up and Down regulated in infectious conditions. (DOCX $17 \mathrm{~kb}$ )

Additional file 4: Figure S2. Energy metabolism of Xac highlighting a set of proteins down-regulated in infectious conditions. (DOCX 783 kb)

Additional file 5: Table S3. Expression profile of Hypothetical and Conserved hypothetical proteins in infectious conditions. (DOCX $15 \mathrm{~kb}$ )

Additional file 6: Figure S3. Phylogenetic and String analysis of Xanthomonas conserved hypothetical protein related to new possible pathogenicity island. (DOCX $615 \mathrm{~kb}$ )

Additional file 7: Table S4. Number of matching peptides and score/ confidence level. (XLSX 223 kb)

\section{Abbreviations}

Avr: Avirulence proteins or T3SS-e; CUT: Carbohidrate Utilization Locus; DAl: Days After Inoculation or Days After Infection; DSF: Diffusible Signal Factor; EPS: Exopolysaccharides; ETI: Effector-Triggered Immunity; $\mathrm{H}_{2} \mathrm{O}_{2}$ : Hydrogen peroxide; LPS: Lipopolysaccharydes; MAP(K): MitogenAssociated Protein (kinase); MudPIT: Multidimensional Protein Identification Technology; NB: Nutriente Broth; $\mathrm{O}_{2}^{*}$ : Superoxide anion radical; $\mathrm{OH}^{*}$ : Hydroxyl radical; PAMPs: Pathogen-associated molecular pattern; PII: Plant-Innate Immunity; POB: Plants` Oxidative Burst; PTI: PAMP-Triggered Immunity; R$\mathrm{OOH}$ : Organic Peroxide; ROS: Reactive Oxygen Species; T3SS: Type 3 Secretion System; T4P: Type IV pili; TBDRs: TonB-Dependent Receptors; Xac: Xanthomonas citri subsp. citri or Xanthomonas axonopodis pv. citri.

\section{Acknowledgements}

We acknowledge the Mass Spectrometry Laboratory at Brazilian Biosciences National Laboratory, CNPEM-ABTLUS, Campinas, Brazil for its support with the mass spectrometry analysis.

\section{Funding}

MR Soares received a post-doctoral scholarship from FAPESP (Fundação de Amparo à Pesquisa do Estado de São Paulo). AP Facincani received a PhD scholarship from CAPES. JCS benefits from a CNPq Principal Investigator fellowship. The biological experiments were conducted in Dr. JA Ferro's laboratory. This work was funded in part by a grant from Fundação de Amparo à Pesquisa do Estado de São Paulo - FAPESP (04/02006-7) for the biological tests, by a grant from Fundação de Amparo à Pesquisa do Estado de Minas Gerais (CBB-APQ-04425-10) for Xac functional database creation, and by BIGA grant (CAPES 3385/2013). The funders had no role in study design, data collection and analysis, decision to publish, or preparation of the manuscript.

\section{Availability of data and materials}

The mass spectrometry proteomics data have been deposited to the ProteomeXchange via MassIVE dataset submission workflow with the dataset identifier MSV000080041.

\section{Author's contributions}

MS, MF, FG, JF and JO conceived and designed proteome experiments. AF, RF performed proteome experiments and analysis. AF, CF, RF, MS, LM, EF, JS analyzed proteome data. CF, JO, JF prepared the mutant strain and analyzed in vivo phenotypic change. MS, MF, FG, JF, JO contributed with reagents, materials and analysis tools. LM, MS, EF, RA, AF, JO, CG prepared the figures and tables. All authors contributed to wrote, revision, final read and approved the manuscript.

\section{Ethics approval and consent to participate}

IAPAR is the center that maintains and distributes the isolate to those interested in doing scientific research. The only requirement of the Institute is to be cited in the articles as the promoter of the isolate. The same isolate was used for genomic sequencing in mid-2002 (see Nature 417, 459-463). 


\section{Consent for publication}

Not applicable.

\section{Competing interests}

The authors have declared that no competing interests exist.

\section{Publisher's Note}

Springer Nature remains neutral with regard to jurisdictional claims in published maps and institutional affiliations.

\section{Author details}

'Departamento de Ciências Biológicas (DECBI), Instituto de Ciências Exatas e Biológicas (ICEB), Universidade Federal de Ouro Preto (UFOP), Ouro Preto, MG, Brazil. ${ }^{2}$ Núcleo de Pesquisas em Ciências Biológicas (NUPEB), Universidade Federal de Ouro Preto, Ouro Preto, MG, Brazil. ${ }^{3}$ Departamento de Bioquímica (DBq), Instituto de Química (IQ), Universidade Federal do Rio de Janeiro (UFRJ), Rio de Janeiro, RJ, Brazil. ${ }^{4}$ Faculdade de Ciências Agrárias e Veterinárias de Jaboticabal, UNESP - Universidade Estadual Paulista, Departamento de Tecnologia, Jaboticabal, SP, Brazil. ${ }^{5}$ Instituto de Química, Universidade Estadual de Campinas (UNICAMP), Campinas, SP, Brazil. ${ }^{6}$ Departamento de Bioquímica (DB), Instituto de Química (IQ), Universidade de São Paulo (USP), São Paulo, SP, Brazil. ${ }^{7}$ Departamento de Ciências Biológicas (DCB), Universidade Federal de São Paulo (UNIFESP), Diadema, SP, Brazil. ${ }^{8}$ Biocomplexity Institute, Virginia Tech, Blacksburg, VA, USA.

Received: 12 December 2016 Accepted: 1 July 2017

Published online: 11 July 2017

\section{References}

1. Bitancourt AA. O cancro cítrico. Biológico. 1957;23:101-11.

2. Timmer LW, Gamsey SM, Graham JH: Compendium of citrus disease. In. Saint Paul - USA.: The American Phytopatological Society Press; 2000.

3. Bock CH, Parker PE, Cook AZ, Gottwald TR. Factors affecting infection of citrus with Xanthomonas axonopodis pv. citri. Phytopathology. 2006;96(6):S14.

4. Brunings AM, Gabriel DW. Xanthomonas citri: breaking the surface. Mol Plant Pathol. 2003;4(3):141-57.

5. Goto M, Ohta K, Okabe N. Studies on saprophytic survival of Xanthomonas citri (Hasse) Dowson. 2. Longevity and survival density of the bacterium on artificially infested weeds, plant residues, and soils. Ann Phytopathol Soc Jpn. 1975;41:141-7.

6. Graham JH, Mcguire RG, Miller JW. Survival of Xanthomonas campestris pv citri in Citrus plant debris and soil in Florida and Argentina. Plant Dis. 1987; 71(12):1094-8.

7. Pruvost O, Boher B, Brocherieux C, Nicole M, Chiroleu F. Survival of Xanthomonas axonopodis pv. citri in leaf lesions under tropical environmental conditions and simulated splash dispersal of inoculum. Phytopathology. 2002;92(4):336-46.

8. Freeman BC, Beattie GA: An overview of plant defenses against pathogens and herbivores. In: The plant health instructor. Saint Paul - USA: The American Phytopathological Society; 2008

9. Ryan RP, Vorholter FJ, Potnis N, Jones JB, Van Sluys MA, Bogdanove AJ, Dow JM. Pathogenomics of Xanthomonas: understanding bacterium-plant interactions. Nat Rev Microbiol. 2011;9(5):344-55.

10. Tsuda K, Katagiri F. Comparing signaling mechanisms engaged in patterntriggered and effector-triggered immunity. Curr Opin Plant Biol. 2010; 13(4):459-65.

11. Navarro L, Zipfel C, Rowland O, Keller I, Robatzek S, Boller T, Jones JDG. The transcriptional innate immune response to flg22. Interplay and overlap with Avr gene-dependent defense responses and bacterial pathogenesis. Plant Physiol. 2004;135(2):1113-28.

12. Zou H, Gowda S, Zhou L, Hajeri S, Chen G, Duan Y. The Destructive Citrus Pathogen, 'Candidatus Liberibacter asiaticus' Encodes a Functional Flagellin Characteristic of a Pathogen-Associated Molecular Pattern. PLoS ONE. 2012; 7(9): e46447. https://doi.org/10.1371/journal.pone.0046447.

13. Petrocelli S, Tondo ML, Daurelio LD, Orellano EG. Modifications of Xanthomonas axonopodis pv. citri Lipopolysaccharide Affect the Basal Response and the Virulence Process during Citrus Canker. PLoS ONE. 2012 7(7):e40051. https://doi.org/10.1371/journal.pone.0040051.

14. Hueck CJ. Type III protein secretion systems in bacterial pathogens of animals and plants. Microbiol Mol Biol R. 1998;62(2):379-+.
15. Boller T, Felix G. A renaissance of elicitors: perception of microbe-associated molecular patterns and danger signals by pattern-recognition receptors. Annu Rev Plant Biol. 2009;60:379-406.

16. Vellosillo T, Vicente J, Kulasekaran S, Hamberg M, Castresana C. Emerging complexity in reactive oxygen species production and signaling during the response of plants to pathogens. Plant Physiol. 2010;154(2):444-8.

17. Jones JDG, Dangl JL. The plant immune system. Nature. 2006;444(7117):323-9.

18. Kim JG, Li XY, Roden JA, Taylor KW, Aakre CD, Su B, Lalonde S, Kirik A, Chen YH, Baranage G, et al. Xanthomonas T3S Effector XopN suppresses PAMP-triggered immunity and interacts with a tomato atypical receptor-like Kinase and TFT1. Plant Cell. 2009;21(4):1305-23.

19. Lamb C, Dixon RA. The oxidative burst in plant disease resistance. Annu Rev Plant Physiol Plant Mol Biol. 1997:48:251-75.

20. Cooke MS, Evans MD, Dizdaroglu M, Lunec J. Oxidative DNA damage: mechanisms, mutation, and disease. FASEB J. 2003;17(10):1195-214.

21. Smith SG, Wilson TJG, Dow JM, Daniels MJ. A gene for superoxide dismutase from Xanthomonas campestris pv campestris and its expression during bacterial-plant interactions. Mol Plant Microbe In. 1996;9(7):584-93.

22. Vattanaviboon $\mathrm{P}$, Sriprang $\mathrm{R}$, Mongkolsuk S. Catalase has a novel protective role against electrophile killing of Xanthomonas. Microbiol-Uk. 2001;147:491-8.

23. Loprasert S, Whangsuk W, Sallabhan R, Mongkolsuk S. The unique glutathione reductase from Xanthomonas campestris: gene expression and enzyme characterization. Biochem Biophys Res Commun. 2005;331(4):1324-30.

24. Jittawuttipoka T, Buranajitpakorn S, Vattanaviboon P, Mongkolsuk S. The Catalase-Peroxidase KatG is required for virulence of Xanthomonas campestris pv. campestris in a host plant by providing protection against low levels of $\mathrm{H}_{2} \mathrm{O}_{2}$. J Bacteriol. 2009;191(23):7372-7.

25. Tondo ML, Petrocelli S, Ottado J, Orellano EG. The Monofunctional Catalase KatE of Xanthomonas axonopodis pv. citri Is Required for Full Virulence in Citrus Plants. PLoS ONE. 2010;5(5):e10803. https://doi.org/10.1371/journal. pone.0010803.

26. Facincani AP, Moreira LM, Soares MR, Ferreira CB, Ferreira RM, Ferro MIT, Ferro JA, Gozzo FC, de Oliveira JCF. Comparative proteomic analysis reveals that T3SS, Tfp, and xanthan gum are key factors in initial stages of Citrus sinensis infection by Xanthomonas citri subsp. citri. Funct Integr Genomics. 2014;14(1):205-17.

27. Wengelnik K, Marie C, Russel M, Bonas U. Expression and localization of HrpA1, a protein of Xanthomonas campestris pv. vesicatoria essential for pathogenicity and induction of the hypersensitive reaction. J Bacteriol. 1996;178(4):1061-9.

28. Moreira LM, Facincani AP, Ferreira CB, Ferreira RM, Ferro MI, Gozzo FC, de Oliveira JC, Ferro JA, Soares MR. Chemotactic signal transduction and phosphate metabolism as adaptive strategies during citrus canker induction by Xanthomonas citri. Funct Integr Genomics. 2015;15(2):197-210.

29. Wadhawan S, Gautam S, Sharma A. Metabolic stress-induced programmed cell death in Xanthomonas. FEMS Microbiol Lett. 2010:312(2):176-83.

30. $\mathrm{Xu} \mathrm{XQ}, \mathrm{Pan} \mathrm{SQ}$. An Agrobacterium catalase is a virulence factor involved in tumorigenesis. Mol Microbiol. 2000;35(2):407-14.

31. Santos R, Franza T, Laporte ML, Sauvage C, Touati D, Expert D. Essential role of superoxide dismutase on the pathogenicity of Erwinia chrysanthemi strain 3937. Mol Plant-Microbe Interact. 2001;14(6):758-67.

32. Ritz D, Beckwith J. Roles of thiol-redox pathways in bacteria. Annu Rev Microbiol. 2001:55:21-48.

33. Mongkolsuk S, Praituan W, Loprasert S, Fuangthong M, Chamnongpol S. Identification and characterization of a new organic hydroperoxide resistance (ohr) gene with a novel pattern of oxidative stress regulation from Xanthomonas campestris pv. phaseoli. J Bacteriol. 1998;180(10):2636-43.

34. Sukchawalit R, Loprasert S, Atichartpongkul S, Mongkolsuk S. Complex regulation of the organic hydroperoxide resistance gene (ohr) from Xanthomonas involves OhrR, a novel organic peroxide-inducible negative regulator, and posttranscriptional modifications. J Bacteriol. 2001;183(15):4405-12.

35. Vattanaviboon P, Whangsuk W, Panmanee W, Klomsiri C, Dharmsthiti S, Mongkolsuk S. Evaluation of the roles that alkyl hydroperoxide reductase and Ohr play in organic peroxide-induced gene expression and protection against organic peroxides in Xanthomonas campestris. Biochem Biophys Res Commun. 2002;299(2):177-82.

36. Klomsiri C, Panmanee W, Dharmsthiti S, Vattanaviboon P, Mongkolsuk S. Novel roles of ohrR-ohr in Xanthomonas sensing, metabolism, and physiological adaptive response to lipid hydroperoxide. J Bacteriol. 2005;187(9):3277-81.

37. Atichartpongkul S, Loprasert S, Vattanaviboon P, Whangsuk W, Helmann JD, Mongkolsuk S. Bacterial Ohr and OsmC paralogues define two protein families with distinct functions and patterns of expression. Microbiol-Sgm. 2001;147:1775-82. 
38. Petersohn A, Brigulla M, Haas S, Hoheisel JD, Volker U, Hecker M. Global analysis of the general stress response of Bacillus subtilis. J Bacteriol. 2001; 183(19):5617-31.

39. Rince A, Uguen M, Le Breton Y, Giard JC, Flahaut S, Dufour A, Auffray Y. The Enterococcus faecalis gene encoding the novel general stress protein Gsp62. Microbiol-Sgm. 2002;148:703-11.

40. Andrews SC, Robinson AK, Rodriguez-Quinones F. Bacterial iron homeostasis. FEMS Microbiol Rev. 2003;27(2-3):215-37

41. Ma Q, Yang Z, Pu M, Peti W, Wood TK. Engineering a novel c-di-GMP-binding protein for biofilm dispersal. Environ Microbiol. 2011;13(3):631-42.

42. Dow JM, Fouhy Y, Lucey JF, Ryan RP. The HD-GYP domain, cyclic Di-GMP signaling, and bacterial virulence to plants. Mol Plant Microbe In. 2006; 19(12):1378-84.

43. Franza T, Expert D. Role of iron homeostasis in the virulence of phytopathogenic bacteria: an 'a la carte' menu. Mol Plant Pathol. 2013;14(4):429-38.

44. Calhoun LN, Kwon YM. Structure, function and regulation of the DNAbinding protein Dps and its role in acid and oxidative stress resistance in Escherichia coli: a review. J Appl Microbiol. 2011;110(2):375-86.

45. Carrondo MA. Ferritins, iron uptake and storage from the bacterioferritin viewpoint. EMBO J. 2003;22(9):1959-68.

46. Shimizu K. Regulation Systems of Bacteria such as Escherichia coli in response to nutrient limitation and environmental stresses. Meta. 2013; $4(1): 1-35$

47. Boulanger A, Zischek C, Lautier M, Jamet S, Rival P, Carrere S, Arlat M, Lauber E. The plant pathogen Xanthomonas campestris pv campestris exploits N-acetylglucosamine during infection. mBio. 2014;5(5):e01527-14.

48. Blanvillain S, Meyer D, Boulanger A, Lautier M, Guynet C, Denance N, Vasse J, Lauber E, Arlat M. Plant carbohydrate scavenging through tonB-dependent receptors: a feature shared by phytopathogenic and aquatic bacteria. PLoS One. 2007;2(2):e224.

49. Aini LQ, Hirata $H$, Tsuyumu S. A TonB-dependent transducer is responsible for regulation of pathogenicity-related genes in Xanthomonas axonopodis pv. citri. J Gen Plant Pathol. 2010;76(2):132-42.

50. Etchegaray A, Silva-Stenico ME, Moon DH, Tsai SM. In silico analysis of nonribosomal peptide synthetases of Xanthomonas axonopodis pv. citri: identification of putative siderophore and lipopeptide biosynthetic genes. Microbiol Res. 2004;159(4):425-37.

51. Zimaro T, Thomas L, Marondedze C, Garavaglia BS, Gehring C, Ottado J, Gottig N. Insights into Xanthomonas axonopodis pv. citri biofilm through proteomics. Bmc Microbiol. 2013;13:186. doi:10.1186/ 1471-2180-13-186

52. Winter G, Todd CD, Trovato M, Forlani G, Funck D. Physiological implications of arginine metabolism in plants. Front Plant Sci. 2015;6:534.

53. Klessig DF, Durner J, Noad R, Navarre DA, Wendehenne D, Kumar D, Zhou JM, Shah J, Zhang SQ, Kachroo P, et al. Nitric oxide and salicylic acid signaling in plant defense. Proc Natl Acad Sci U S A 2000. 97(16):8849-+

54. Koide T, Zaini PA, Moreira LM, Vencio RZN, Matsukuma AY, Durham AM, Teixeira DC, El-Dorry H, Monteiro PB, da Silva ACR, et al. DNA microarraybased genome comparison of a pathogenic and a nonpathogenic strain of Xylella fastidiosa delineates genes important for bacterial virulence. J Bacteriol. 2004;186(16):5442-9.

55. Woodard SI, Dailey HA. Regulation of heme biosynthesis in Escherichia coli. Arch Biochem Biophys. 1995;316(1):110-5.

56. Xu K, Elliott T. An oxygen-dependent coproporphyrinogen oxidase encoded by the hemF gene of Salmonella typhimurium. J Bacteriol. 1993;175(16):4990-9.

57. Mukhopadhyay S, Schellhorn HE. Identification and characterization of hydrogen peroxide-sensitive mutants of Escherichia coli: genes that require OxyR for expression. J Bacteriol. 1997;179(2):330-8.

58. Rodriguez-Rojas A, Blazquez J. The Pseudomonas aeruginosa pfp/ gene plays an antimutator role and provides general stress protection. J Bacteriol. 2009; 191(3):844-50

59. Denny TP. Involvement of bacterial polysaccharides in plant pathogenesis. Annu Rev Phytopathol. 1995;33:173-97.

60. Zipfel C. Pattern-recognition receptors in plant innate immunity. Curr Opin Immunol. 2008;20(1):10-6.

61. Rick PD, Young DA. Relationship between cell-death and altered lipid-a synthesis in a temperature-sensitive lethal mutant of Salmonella-Typhimurium that is conditionally defective in 3-Deoxy-D-Manno-Octulosonate-8-phosphate synthesis. J Bacteriol. 1982;150(2):456-64.
62. Mochalkin I, Knafels JD, Lightle S. Crystal structure of LpxC from Pseudomonas aeruginosa complexed with the potent BB-78485 inhibitor. Protein Sci. 2008; 17(3):450-7.

63. Desaki Y, Miya A, Venkatesh B, Tsuyumu S, Yamane H, Kaku H, Minami E, Shibuya N. Bacterial lipopolysaccharides induce defense responses associated with programmed cell death in rice cells. Plant Cell Physiol. 2006;47(11):1530-40.

64. Cigana $\mathrm{C}$, Curcurù L, Leone MR, leranò $T$, Lorè $\mathrm{NI}$, Bianconi I, et al. Pseudomonas aeruginosa Exploits Lipid A and Muropeptides Modification as a Strategy to Lower Innate Immunity during Cystic Fibrosis Lung Infection. PLoS ONE. 2009; 4(12):e8439. https://doi.org/10.1371/journal.pone.0008439.

65. Koplin R, Wang G, Hotte B, Priefer UB, Puhler A. A 3.9-kb DNA region of Xanthomonas campestris pv campestris that is necessary for Lipopolysaccharide production encodes a set of enzymes involved in the synthesis of Dtdp-Rhamnose. J Bacteriol. 1993;175(24):7786-92.

66. Moreira LM, Almeida NF, Potnis N, Digiampietri LA, Adi SS, Bortolossi JC, da Silva AC, da Silva AM, de Moraes FE, de Oliveira JC, et al. Novel insights into the genomic basis of citrus canker based on the genome sequences of two strains of Xanthomonas fuscans subsp aurantifolii. BMC Genomics. 2010;11

67. Zhang Y, Jalan N, Zhou X, Goss E, Jones JB, Setubal JC, Deng X, Wang N. Positive selection is the main driving force for evolution of citrus cankercausing Xanthomonas. The ISME journal. 2015:

68. Yan Q, Hu XF, Wang NA. The novel virulence-related gene $n / x A$ in the lipopolysaccharide cluster of Xanthomonas citri ssp citri is involved in the production of lipopolysaccharide and extracellular polysaccharide, motility, biofilm formation and stress resistance. Mol Plant Pathol. 2012;13(8):923-34.

69. Huang TP, Somers EB, Wong ACL. Differential biofilm formation and motility associated with lipopolysaccharide/exopolysaccharide-coupled biosynthetic genes in Stenotrophomonas maltophilia. J Bacteriol. 2006;188(8):3116-20.

70. Patil PB, Sonti RV. Variation suggestive of horizontal gene transfer at a lipopolysaccharide (lps) biosynthetic locus in Xanthomonas oryzae pv. oryzae, the bacterial leaf blight pathogen of rice. BMC Microbiol. 2004;4:40.

71. Wang JC, So BH, Kim JH, Park YJ, Lee BM, Kang HW. Genome-wide identification of pathogenicity genes in Xanthomonas oryzae pv. oryzae by transposon mutagenesis. Plant Pathol. 2008;57(6):1136-45.

72. Ngo PT, Kim JK, Kim H, Jung J, Ahn YJ, Kim JG, Lee BM, Kang HW, Kang LW. Expression, crystallization and preliminary $X$-ray crystallographic analysis of XometC, a cystathionine gamma-lyase-like protein from Xanthomonas oryzae pv. oryzae. Acta Crystallogr Sect F: Struct Biol Cryst Commun. 2008; 64(Pt 8):750-3.

73. Messerschmidt A, Worbs M, Steegborn C, Wahl MC, Huber R, Laber B, Clausen T. Determinants of enzymatic specificity in the Cys-met-metabolism PLP-dependent enzymes family: crystal structure of cystathionine gammalyase from yeast and intrafamiliar structure comparison. Biol Chem. 2003; 384(3):373-86.

74. Koplin R, Arnold W, Hotte B, Simon R, Wang G, Puhler A. Genetics of xanthan production in Xanthomonas campestris: the xanA and xanB genes are involved in UDP-glucose and GDP-mannose biosynthesis. J Bacteriol. 1992;174(1):191-9.

75. Guo YP, Sagaram US, Kim JS, Wang N. Requirement of the galU gene for polysaccharide production by and Pathogenicity and growth in Planta of Xanthomonas citri subsp citri. Appl Environ Microbiol. 2010;76(7):2234-42.

76. Guo Y, Sagaram US, Wang N. The galU gene is required for survival of Xanthomonas axonopodis pv. citri in planta and its pathogenicity. Phytopathology. 2009;99(6):S48

77. Deng WL, Lin YC, Lin RH, Wei CF, Huang YC, Peng HL, Huang HC. Effects of galU mutation on Pseudomonas syringae-plant interactions. Mol PlantMicrobe Interact. 2010;23(9):1184-96.

78. Bakkevig K, Sletta H, Gimmestad M, Aune R, Ertesvag H, Degnes K, Christensen BE, Ellingsen TE, Valla S. Role of the Pseudomonas fluorescens alginate lyase $(\mathrm{Alg} \mathrm{L})$ in clearing the periplasm of alginates not exported to the extracellular environment. J Bacteriol. 2005;187(24):8375-84.

79. Wingender J. Interactions of alginate with exoenzymes. In: Gacesa P, Russel $\mathrm{NJ}$, editors. Pseudomonas infection and alginates biochemistry, genetics and pathology. London: Chaoman \& Hall; 1990. p. 160-80.

80. Wong TY, Preston LA, Schiller NL. Alginate lyase: review of major sources and enzyme characteristics, structure-function analysis, biological roles, and applications. Annu Rev Microbiol. 2000;54:289-340.

81. Boyd A, Chakrabarty AM. Role of alginate Lyase in cell detachment of Pseudomonas-Aeruginosa. Appl Environ Microbiol. 1994;60(7):2355-9.

82. Fett WF, Osman SF, Fishman ML, Siebles TS. Alginate production by plantpathogenic Pseudomonads. Appl Environ Microbiol. 1986;52(3):466-73. 
83. Silipo A, Erbs G, Shinya T, Dow JM, Parrilli M, Lanzetta R, Shibuya N, Newman MA, Molinaro A. Glyco-conjugates as elicitors or suppressors of plant innate immunity. Glycobiology. 2010;20(4):406-19.

84. Li J, Wang N. Genome-wide mutagenesis of Xanthomonas axonopodis pv. citri reveals novel genetic determinants and regulation mechanisms of biofilm formation. PLoS One. 2011;6(7):e21804.

85. Zhu XN, Long F, Chen YH, Knochel S, She QX, Shi XM. A putative ABC transporter is involved in negative regulation of biofilm formation by Listeria monocytogenes. Appl Environ Microbiol. 2008;74(24):7675-83.

86. Vanderlinde EM, Harrison JJ, Muszynski A, Carlson RW, Turner RJ, Yost CK. Identification of a novel $A B C$ transporter required for desiccation tolerance, and biofilm formation in Rhizobium leguminosarum bv. viciae 3841. FEMS Microbiol Ecol. 2010;71(3):327-40.

87. Craig L, Pique ME, Tainer JA. Type IV pilus structure and bacterial pathogenicity. Nat Rev Microbiol. 2004;2(5):363-78.

88. Whitchurch CB, Hobbs M, Livingston SP, Krishnapillai V, Mattick JS. Characterisation of a Pseudomonas aeruginosa twitching motility gene and evidence for a specialised protein export system widespread in eubacteria. Gene. 1991;101(1):33-44.

89. Meng Y, Li Y, Galvani CD, Hao G, Turner JN, Burr TJ, Hoch HC. Upstream migration of Xylella fastidiosa via pilus-driven twitching motility. J Bacteriol. 2005;187(16):5560-7.

90. Killiny N, Almeida RP. Xylella fastidiosa afimbrial adhesins mediate cell transmission to plants by leafhopper vectors. Appl Environ Microbiol. 2009; 75(2):521-8

91. Yeung ATY, Torfs ECW, Jamshidi F, Bains M, Wiegand I, Hancock REW, Overhage J: Swarming of Pseudomonas aeruginosa is controlled by a broad Spectrum of transcriptional regulators, Including MetR J Bacteriol 2009, 191(18):5592-5602.

92. Dominguez-Escobar J, Chastanet A, Crevenna AH, Fromion V, Wedlich-Soldner $\mathrm{R}$, Carballido-Lopez R. Processive movement of MreB-associated cell wall biosynthetic complexes in bacteria. Science. 2011;333(6039):225-8.

93. Cowles KN, Gitai Z. Surface association and the MreB cytoskeleton regulate pilus production, localization and function in Pseudomonas aeruginosa. Mol Microbiol. 2010;76(6):1411-26.

94. Becker P, Hufnagle W, Peters $G$, Herrmann M. Detection of differential gene expression in biofilm-forming versus planktonic populations of Staphylococcus aureus using micro-representational-difference analysis. Appl Environ Microbiol. 2001;67(7):2958-65

95. Lattif AA, Chandra J, Chang J, Liu S, Zhou G, Chance MR, Ghannoum MA, Mukherjee PK. Proteomics and pathway mapping analyses reveal phasedependent over-expression of proteins associated with carbohydrate metabolic pathways in Candida albicans biofilms. The Open Proteomics Journal. 2008;1:5-26.

96. Chromy BA, Choi MW, Murphy GA, Gonzales AD, Corzett CH, Chang BC, Fitch JP, McCutchen-Maloney SL. Proteomic characterization of Yersinia pestis virulence. J Bacteriol. 2005;187(23):8172-80.

97. Matthysse AG, Yarnall H, Boles SB, McMahan S. A region of the Agrobacterium tumefaciens chromosome containing genes required for virulence and attachment to host cells. Bba-Gene Struct Expr. 2000;1490(1-2):208-12.

98. Barber CE, Tang JL, Feng JX, Pan MQ, Wilson TJ, Slater H, Dow JM, Williams $P$, Daniels MJ. A novel regulatory system required for pathogenicity of Xanthomonas campestris is mediated by a small diffusible signal molecule. Mol Microbiol. 1997;24(3):555-66.

99. Tang JL, Liu YN, Barber CE, Dow JM, Wootton JC, Daniels MJ. Genetic and molecular analysis of a cluster of rpf genes involved in positive regulation of synthesis of extracellular enzymes and polysaccharide in Xanthomonas campestris pathovar campestris. Mol Gen Genet. 1991; 226(3):409-17.

100. Wilson TJ, Bertrand N, Tang JL, Feng JX, Pan MQ, Barber CE, Dow JM, Daniels MJ. The rpfA gene of Xanthomonas campestris pathovar campestris, which is involved in the regulation of pathogenicity factor production, encodes an aconitase. Mol Microbiol. 1998;28(5):961-70.

101. Kulikova T, Akhtar R, Aldebert P, Althorpe N, Andersson M, Baldwin A, Bates K, Bhattacharyya S, Bower L, Browne P, et al. EMBL Nucleotide Sequence Database in 2006. Nucleic Acids Res. 2007;35(Database issue):D16-20.

102. Chan YY, Chua KL. The Burkholderia pseudomallei BpeAB-OprB efflux pump: expression and impact on quorum sensing and virulence. J Bacteriol. 2005; 187(14):4707-19.

103. White FF, Potnis N, Jones JB, Koebnik R. The type III effectors of Xanthomonas, Mol Plant Pathol. 2009;10(6):749-66.
104. Oh HS, Kvitko BH, Morello JE, Collmer A. Pseudomonas syringae lytic transglycosylases coregulated with the type III secretion system contribute to the translocation of effector proteins into plant cells. J Bacteriol. 2007; 189(22):8277-89.

105. Laia ML, Moreira LM, Dezajacomo J, Brigati JB, Ferreira CB, Ferro MI, Silva AC, Ferro JA, Oliveira JC: New genes of Xanthomonas citri subsp. citri involved in pathogenesis and adaptation revealed by a transposon-based mutant library. Bmc Microbiol. 2009;9:12. doi:10.1186/1471-2180-9-12.

106. Ferreira RM, de Oliveira AC, Moreira LM, Belasque J Jr, Gourbeyre E, Siguier P, Ferro MI, Ferro JA, Chandler M, Varani AM. A TALE of transposition: Tn3like transposons play a major role in the spread of pathogenicity determinants of Xanthomonas citri and other xanthomonads. MBio. 2015; 6(1):e02505-14

107. Tielen P, Rosenau F, Wilhelm S, Jaeger KE, Flemming HC, Wingender J. Extracellular enzymes affect biofilm formation of mucoid Pseudomonas aeruginosa. Microbiology. 2010;156(Pt 7):2239-52.

108. Lee YA, Sung AN, Liu TF, Lee YS. Combination of chromogenic differential medium and estA-specific PCR for isolation and detection of phytopathogenic Xanthomonas spp. Appl Environ Microbiol. 2009;75(21):6831-8.

109. Yan Q, Wang N. The ColR/ColS two-component system plays multiple roles in the pathogenicity of the citrus canker pathogen Xanthomonas citri subsp. citri. J Bacteriol. 2011;193(7):1590-9.

110. Subramoni S, Pandey A, Vishnu Priya MR, Patel HK, Sonti RV. The ColRS system of Xanthomonas oryzae pv. oryzae is required for virulence and growth in iron-limiting conditions. Mol Plant Pathol. 2012;13(7):690-703.

111. Matas IM, Lambertsen L, Rodriguez-Moreno L, Ramos C. Identification of novel virulence genes and metabolic pathways required for full fitness of Pseudomonas savastanoi pv. savastanoi in olive (Olea europaea) knots. New Phytol. 2012;196(4):1182-96.

112. An SQ, Caly DL, McCarthy Y, Murdoch SL, Ward J, Febrer M, Dow JM, Ryan RP. Novel cyclic di-GMP effectors of the YajQ protein family control bacterial virulence. PLoS Pathog. 2014;10(10):e1004429.

113. Kuhn J, Briegel A, Morschel E, Kahnt J, Leser K, Wick S, Jensen GJ, Thanbichler M. Bactofilins, a ubiquitous class of cytoskeletal proteins mediating polar localization of a cell wall synthase in Caulobacter crescentus. EMBO J. 2010;29(2):327-39.

114. Bulyha I, Lindow S, Lin L, Bolte K, Wuichet K, Kahnt J, van der Does C, Thanbichler M, Sogaard-Andersen L. Two small GTPases act in concert with the bactofilin cytoskeleton to regulate dynamic bacterial cell polarity. Dev Cell. 2013;25(2):119-31.

115. Rajagopala SV, Titz B, Goll J, Parrish JR, Wohlbold K, McKevitt MT, Palzkill T, Mori H, Finley RL, Uetz P. The protein network of bacterial motility. Mol Syst Biol. 2007;3

116. Bucker R, Heroven AK, Becker J, Dersch P, Wittmann C. The pyruvatetricarboxylic acid cycle node: a focal point of virulence control in the enteric pathogen Yersinia pseudotuberculosis. J Biol Chem. 2014;289(43):30114-32.

117. Bignucolo A, Appanna VP, Thomas SC, Auger C, Han S, Omri A, Appanna VD. Hydrogen peroxide stress provokes a metabolic reprogramming in Pseudomonas fluorescens: enhanced production of pyruvate. J Biotechnol. 2013;167(3):309-15.

118. Bredenbruch F, Geffers R, Nimtz M, Buer J, Haussler S. The Pseudomonas aeruginosa quinolone signal (PQS) has an iron-chelating activity. Environ Microbiol. 2006;8(8):1318-29.

119. Diggle SP, Matthijs S, Wright VJ, Fletcher MP, Chhabra SR, Lamont IL, Kong X, Hider RC, Cornelis P, Camara M, et al. The Pseudomonas aeruginosa 4quinolone signal molecules $\mathrm{HHQ}$ and $\mathrm{PQS}$ play multifunctional roles in quorum sensing and iron entrapment. Chem Biol. 2007;14(1):87-96.

120. Haussler S, Becker T. The Pseudomonas quinolone signal (PQS) balances life and death in Pseudomonas aeruginosa populations. PLoS Pathog. 2008;4(9): e1000166.

121. Toyofuku M, Nakajima-Kambe T, Uchiyama $H$, Nomura $N$. The effect of a cell-to-cell communication molecule, Pseudomonas quinolone signal (PQS), produced by $P$. aeruginosa on other bacterial species. Microbes Environ. 2010;25(1):1-7.

122. Subramoni S, Nguyen DT, Sokol PA. Burkholderia cenocepacia ShvR-regulated genes that influence Colony morphology, biofilm formation, and virulence. Infect Immun. 2011;79(8):2984-97.

123. Ermolaeva MD, White O, Salzberg SL. Prediction of operons in microbial genomes. Nucleic Acids Res. 2001;29(5):1216-21.

124. Snel B, Lehmann G, Bork P, Huynen MA. STRING: a web-server to retrieve and display the repeatedly occurring neighbourhood of a gene. Nucleic Acids Res. 2000;28(18):3442-4. 
125. Sugio A, Yang B, White FF. Characterization of the hrpF pathogenicity peninsula of Xanthomonas oryzae pv. oryzae. Mol Plant-Microbe Interact. 2005;18(6):546-54.

126. O'Grady EP, Sokol PA. Burkholderia cenocepacia differential gene expression during host-pathogen interactions and adaptation to the host environment. Front Cell Infect Microbiol. 2011;1:15.

127. Greenshields DL, Liu G, Wei Y. Roles of iron in plant defence and fungal virulence. Plant Signal Behav. 2007;2(4):300-2.

128. Maldonado RF, Sa-Correia I, Valvano MA. Lipopolysaccharide modification in gram-negative bacteria during chronic infection. FEMS Microbiol Rev. 2016; 40(4):480-93.

129. Buttner D, Bonas U. Regulation and secretion of Xanthomonas virulence factors. FEMS Microbiol Rev. 2010;34(2):107-33.

130. Cao B, Liu J, Qin G, Tian S. Oxidative stress acts on special membrane proteins to reduce the viability of Pseudomonas syringae pv tomato. J Proteome Res. 2012;11(10):4927-38

131. da Silva AC, Ferro JA, Reinach FC, Farah CS, Furlan LR, Quaggio RB, MonteiroVitorello CB, Van Sluys MA, Almeida NF, Alves LM, et al. Comparison of the genomes of two Xanthomonas pathogens with differing host specificities. Nature. 2002;417(6887):459-63.

132. Mehta A, Rosato YB. Identification of differentially expressed genes of Xanthomonas axonopodis pv. citri by representational difference analysis of cDNA. Genet Mol Biol. 2005;28(1):140-9.

133. Altschul SF, Gish W, Miller W, Myers EW, Lipman DJ. Basic local alignment search tool. J Mol Biol. 1990;215(3):403-10.

134. Ogata H, Goto S, Sato K, Fujibuchi W, Bono H, Kanehisa M. KEGG: Kyoto encyclopedia of genes and genomes. Nucleic Acids Res. 1999;27(1):29-34.

135. Tatusov RL, Koonin EV, Lipman DJ. A genomic perspective on protein families. Science. 1997;278(5338):631-7.

\section{Submit your next manuscript to BioMed Central and we will help you at every step:}

- We accept pre-submission inquiries

- Our selector tool helps you to find the most relevant journal

- We provide round the clock customer support

- Convenient online submission

- Thorough peer review

- Inclusion in PubMed and all major indexing services

- Maximum visibility for your research

Submit your manuscript at www.biomedcentral.com/submit 